\title{
Clinical utility of biomarkers of endothelial activation in sepsis-a systematic review
}

Katharine Xing ${ }^{1}$, Srinivas Murthy ${ }^{2}$, W Conrad Liles ${ }^{3,4}$ and Jeffrey M Singh ${ }^{4,5^{*}}$

\begin{abstract}
Introduction: A strong biologic rationale exists for targeting markers of endothelial cell (EC) activation as clinically informative biomarkers to improve diagnosis, prognostic evaluation or risk-stratification of patients with sepsis.

Methods: The objective was to review the literature on the use of markers of EC activation as prognostic biomarkers in sepsis. MEDLINE was searched for publications using the keyword 'sepsis' and any of the identified endothelial-derived biomarkers in any searchable field. All clinical studies evaluating markers reflecting activation of ECs were included. Studies evaluating other exogenous mediators of EC dysfunction and studies of patients with malaria and febrile neutropenia were excluded.

Results: Sixty-one studies were identified that fulfilled the inclusion criteria. Overall, published studies report positive correlations between multiple EC-derived molecules and the diagnosis of sepsis, supporting the critical role of EC activation in sepsis. Multiple studies also reported positive associations for mortality and severity of illness, although these results were less consistent than for the presence of sepsis. Very few studies, however, reported thresholds or receiver operating characteristics that would establish these molecules as clinically-relevant biomarkers in sepsis.

Conclusions: Multiple endothelial-derived molecules are positively correlated with the presence of sepsis in humans, and variably correlated to other clinically-important outcomes. The clinical utility of these biomarkers is limited by a lack of assay standardization, unknown receiver operating characteristics and lack of validation. Additional large-scale prospective clinical trials will be required to determine the clinical utility of biomarkers of endothelial activation in the management of patients with sepsis.
\end{abstract}

Keywords: Sepsis, endothelium, biomarker, angiopoietin, coagulation

\section{Introduction}

Sepsis is a complex syndrome that results from a host's response to invasive infection [1,2], and severe sepsis with organ dysfunction and septic shock are leading causes of death in critically ill patients [3]. A tool that would predict prognosis or allow risk-stratification of patients is needed to inform healthcare providers, families and decision makers, and facilitate the study and implementation of evolving therapeutic interventions.

A biomarker is defined as "...a characteristic that is objectively measured as an indicator of normal

\footnotetext{
* Correspondence: jeff.singh@uhn.ca

${ }^{4}$ Department of Medicine, University of Toronto, 1 King's College Circle Medical Sciences Building-Room 2109, Toronto, ON M5S 1A8, Canada Full list of author information is available at the end of the article
}

biological processes, pathogenic processes or pharmacologic responses to therapeutic intervention" [4]. Despite the proposal of over 100 distinct biological molecules as biomarkers for sepsis, no useful single biomarker, or combination thereof, has yet been identified [5].

A hallmark of sepsis is a change in microvascular function. Widespread endothelial damage and apoptosis appears to be directly involved (see Figure 1), with numerous associations observed between sepsis and endothelial cell (EC) activation [6-10]. Consequently, there is a strong biologic rationale for targeting markers of endothelial activation as biomarkers of sepsis. A large number of EC-active molecules have been investigated as potential biomarkers for the early diagnosis, triage and prognostication of sepsis. These include regulators of endothelial activation, such as vascular endothelial
C Biomed Central

() 2012 Xing et al.; licensee BioMed Central Ltd. This is an open access article distributed under the terms of the Creative Commons Attribution License (http://creativecommons.org/licenses/by/2.0), which permits unrestricted use, distribution, and reproduction in any medium, provided the original work is properly cited. 


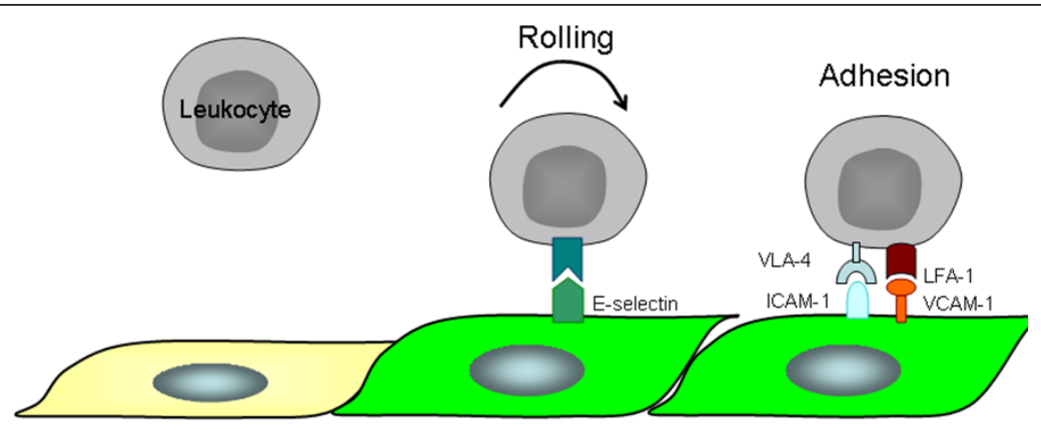

Ang-2 released by Weibel-Palade bodies

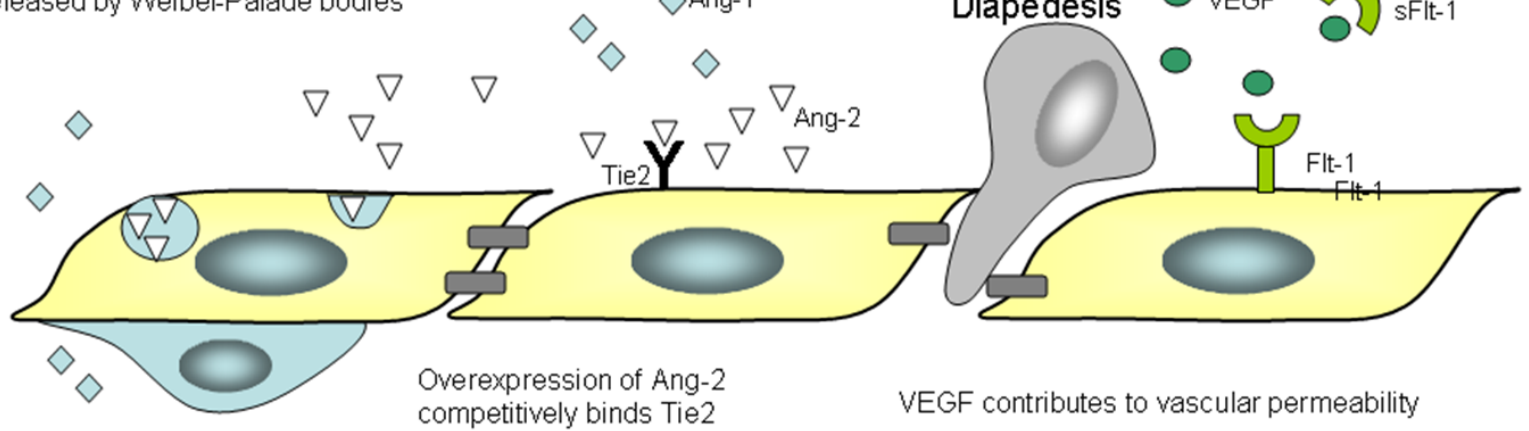

Ang-2 constitutively released by pericytes

Figure 1 Endothelial activation induces increased production of adhesion molecules such as ICAM-1, VCAM-1, E-selectin and Pselectin. E-selectin induces leukocyte rolling, and ICAM-1 and VCAM-1 bind leukocyte function antigen 1 (LFA1) and very late antigen 4 (VLA4), respectively, to induce firm leukocyte adhesion. Activation is partially mediated by VEGF binding to VEGF receptor 1 (VEGFR1, also known as Flt1) and VEGF receptor 2 (VEGFR2). Soluble Flt-1 binds VEGF competitively to render an anti-inflammatory response in the setting of sepsis. Ang-1 is constitutively secreted by pericytes and smooth muscle cells. Upon activation, Ang-2 is rapidly released by Weibel-Palade bodies, competitively interfering with Ang-1/Tie2 signaling and thereby increasing expression of adhesion molecules.

growth factor (VEGF), endocan and the angiopoeitin pathway (Ang-1/2), adhesion molecules such as sICAM-1, sVCAM-1, and sE-selectin-1), mediators of permeability and vasomotor tone (s-Flt and endothelin1 ); and mediators of coagulation (vWF, ADAMTS13).

Given the potential for, and growing interest in, ECderived molecules as biomarkers in sepsis, we conducted a systematic review of the current published literature of biomarkers to determine their performance in predicting the severity of sepsis and clinical outcomes. This systematic review will serve as an update and supplement to other recent reviews in the literature [5,11-14], given the rapidly evolving nature of the field.

\section{Materials and methods}

\section{Data sources}

We systematically and inclusively identified all studies evaluating markers of endothelial activation, (including angiopoietins and sTie2R, sVEGF and sFlt-1, sICAM-1,
sVCAM-1, sE-selectin, endothelin-1, endocan, VWF and ADAMTS13) in sepsis. We electronically searched MEDLINE (1950 to Week 2, September 2011) and EMBASE (1980 to Week 37, 2011) databases for all pertinent English language studies. (Please see Additional file 1, Search Strategy).

\section{Study selection methods}

Study selection was performed independently by three reviewers (KX, SM, JMS), with disagreements resolved through arbitration by a fourth reviewer (WCL). A study was included if it (1) studied adult patients with sepsis or the systemic inflammatory response syndrome (SIRS), or studied patients at risk for sepsis or SIRS, and (2) evaluated a clinical endpoint (the development of sepsis, sepsis severity, development of organ dysfunction or mortality). Studies of patients less than 18 years of age, patients with febrile neutropenia, patients with malaria, interventional clinical trials studying a specific 
intervention or medication and case reports were excluded.

\section{Study data extraction and analysis}

For each of the selected studies, we extracted the biomarker(s) evaluated, study size and patient population, and details of the primary and secondary outcomes. Outcomes of interest for each biomarker were tabulated and compared across studies where appropriate. Study design, standardization of sepsis definition and other methodological data were extracted and each study was subject to the Grading of Recommendations Assessment, Development and Evaluation (GRADE) system for assessing the quality of evidence [15]. Due to the anticipated broad study heterogeneity and disparate study outcomes, we did not attempt to numerically combine or perform a meta-analysis of study results.

\section{Results}

Our search identified 1,243 unique articles (see Figure 2). A total of 84 studies met our predefined inclusion and exclusion criteria, of which a further 23 studies were excluded after retrieval of full-text publication for the following reasons: 14 studies did not report a clinical outcome [16-29], 4 studies did not include a relevant patient population [30-32], 3 studies were interventional trials [33-35], and 2 studies were not in English and the English abstracts provided insufficient information to allow adjudication of study inclusion [36,37]. The remaining 61 studies were included in our review.

All studies were observational designs, including secondary analyses of data collected during prospective clinical trials. Most studies used standard consensus definitions of sepsis. Interpretation of the magnitude of effect or association between biomarkers and sepsis or clinical outcomes was limited by a lack of standardization in individual biomarker assays, an absence of identified or validated thresholds or cut-points in individual biomarker levels, and a lack of reported odds ratios or relative risk. Several studies identified positive associations between biomarker levels and severity of sepsis (for example, sepsis, severe sepsis and septic shock), but given the aforementioned limitations and heterogeneity across studies in this association, we did not deem this to be sufficient evidence of a doseresponse association to upgrade the quality level of these studies given the aforementioned limitations. Consequently, all studies were assigned a GRADE level of 'low quality' with respect to the association between individual biomarker levels and sepsis [15].

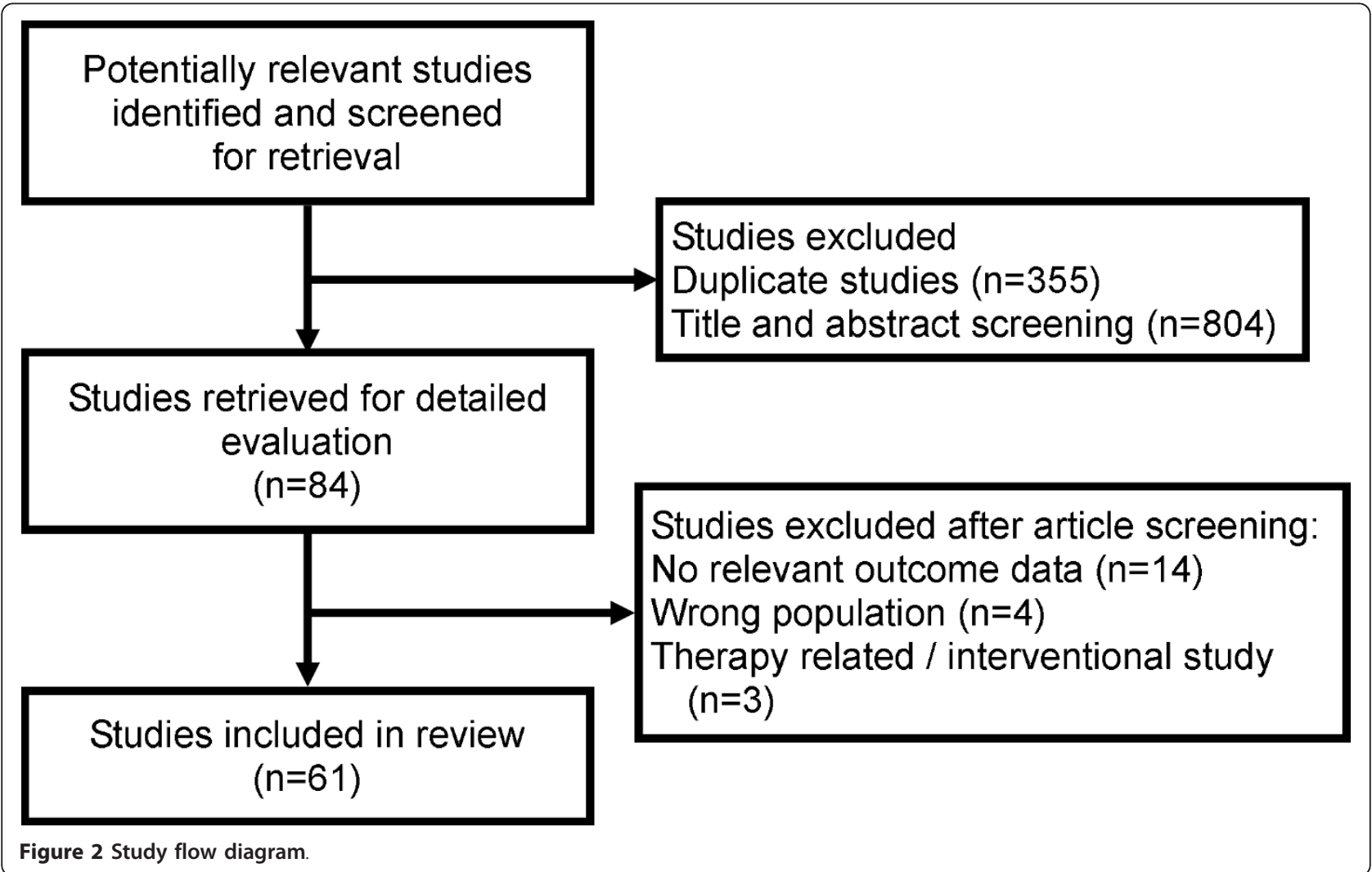




\section{The Angiopoietin system}

We identified 11 studies investigating angiopoietin 2 (Ang-2) as a biomarker in human sepsis (see Table 1Studies Evaluating Angiopoietin-2). All but one were prospective observational studies [38-44], with one secondary analysis of a previously conducted cohort study [45].

\section{Association with sepsis}

Seven studies evaluated the association between Ang-2 levels and sepsis, reporting higher levels of Ang-2 in patients with sepsis compared to patients without sepsis in the ward setting $[43,44]$, the ICU $[38,40,42,45]$, and patients with acute lung injury/acute respiratory distress syndrome (ALI/ARDS) [45]. Ang-2 levels were also higher in sepsis than in either patients with sterile SIRS [40] or healthy controls [41]. Kumpers et al. also reported that Ang-2 concentrations were elevated in all ICU patients (irrespective of sepsis status) compared to healthy controls [42]. One study found that patients who did not have SIRS/sepsis on admission but subsequently developed SIRS/sepsis, had significant increases in Ang-2 over time [40].

There were inconsistent reports of the association between Ang-2 and the severity of sepsis (as defined by sepsis, severe sepsis and septic shock), with one positive study [44] and four studies that failed to observe a consistent correlation [38,39,41,42]. Higher levels of Ang-2 were also reported in patients with severe sepsis compared to septic ICU patients without organ dysfunction $[38,43,44]$, non-septic hospitalized controls $[43,44]$, and ICU patients without SIRS [38].

None of the studies identified a cut point or threshold of circulating Ang-2 that allowed differentiation of patients with sepsis and without sepsis, or stratification of patients with respect to sepsis severity based on baseline or serial serum Ang-2 concentrations.

\section{Association with clinical outcome}

Three studies [39,40,42] observed associations between circulating Ang-2 levels and severity of illness as defined by Acute Physiology and Chronic Health Evaluation II (APACHE II) [46] or Sequential Organ Failure Assessment score (SOFA) [47], and five studies reported a relationship between increasing Ang-2 levels and increasing mortality [39-42,48]. Kumpers et al. found that circulating Ang-2 levels were independently associated with 30-day survival after adjustment for APACHE II score, SOFA score and serum lactate levels [42]. Kranidioti et al. found that Ang-2 concentrations were associated with sepsis-related mortality at baseline and every day for the first seven days in ICU, and Ang-2 levels greater than $9.7 \mathrm{ng} / \mathrm{mL}$ were associated with a three-fold increased risk of sepsis-related mortality [41]. Siner et al. found higher Ang-2 levels were associated with hospital motality, and the patient cohort could be stratified for hospital mortality by admission Ang-2 levels [39]. Ricciuto et al. observed that serial measurements of Ang-2 were associated with 28-day mortality and multiple organ dysfunction (MOD) score [48].

One study found Ang-2 was independently associated with the severity of lung injury as measured by pulmonary leak, and was predictive for the development of ARDS [45]. A second study found an inverse correlation between Ang-2 and $\mathrm{PaO} 2 / \mathrm{FiO} 2$ ratio [49]. Page et al. found that the Ang-2/Ang-1 ratio was significantly increased in patients with invasive streptococcal infection who developed toxic shock syndrome, compared to those with uncomplicated infection [50].

\section{The leukocyte adhesion pathway}

We identified 19 studies investigating SICAM-1 as a sepsis biomarker (see Table 2-Studies evaluating sICAM), 12 studies for sVCAM-1 (see Table 3-Studies Evaluating sVCAM-1), 23 studies for sE-selectin-1 (Table 4-Studies Evaluating sE-selectin-1), and 2 studies for endocan (see Table 5-Studies Evaluating Endocan). All were prospective studies or secondary analyses of prospective studies. These studies focused on emergency room patients with suspected infections or shock [51,52], and critically ill patients admitted to intensive care units, including medical and surgical patients [51,53-76], patients with ventilator-associated pneumonia (VAP) [73], trauma $[62,63,66,67,75]$, and post-cardiopulmonary resuscitation [74].

\section{Soluble ICAM-1 \\ Association with sepsis}

All studies comparing sICAM-1 in septic patients and healthy controls reported higher levels in septic patients $[54,55,58,59,65,66,68]$. sICAM-1 was also found to be significantly higher in sepsis than in patients with trauma [61,62,66,67], postoperative patients [55], patients with other forms of shock [52], and non-septic ICU patients $[59,66,68]$. One study reported that sICAM-1 levels were similar in septic patients and ICU patients without sepsis [65]. Two studies explicitly compared sICAM-1 in patients with sepsis and SIRS [53,68], but only one found higher sICAM-1 in sepsis [53]. Several studies observed that baseline sICAM-1 levels were similar in non-septic patients and healthy controls $[55,59,66]$.

The association between sICAM-1 levels and sepsis severity was variable. Seven studies investigated this association, with four studies reporting higher sICAM-1 levels with increasing severity of sepsis $[59,64,68,77]$ and three negative studies $[53,61,65]$.

\section{Association with clinical outcome}

Eleven studies reported data on mortality. Five of these studies reported that increasing sICAM-1 levels 
Table 1 Studies evaluating angiopoietin-2

\begin{tabular}{|c|c|c|c|c|c|c|}
\hline Study & Year & $\mathrm{N}$ & Population & $\begin{array}{l}\text { Standard Criteria for SIRS/ } \\
\text { Sepsis }\end{array}$ & Association with Sepsis & Other Outcomes \\
\hline $\begin{array}{l}\text { Parikh et al., } \\
\text { [43] }\end{array}$ & 2006 & 51 & $\begin{array}{l}\text { ICU patients with sepsis } \\
\text { (22) and hospitalized } \\
\text { controls (29) }\end{array}$ & 2003 ACCP/SCCM [2] & $\begin{array}{l}\text { Ang-2 higher in patients severe sepsis than patients } \\
\text { with sepsis and controls }(23.2 \text { vs. } 4.8 \text { and } 3.5 \mathrm{ng} / \mathrm{mL} \\
\text { respectively; } P<0.01)\end{array}$ & \\
\hline $\begin{array}{l}\text { Van der } \\
\text { Heijden } \\
\text { et al., [45] }\end{array}$ & 2008 & 112 & $\begin{array}{l}\text { Mechanically ventilated } \\
\text { patients, with sepsis (24) } \\
\text { and without (88) }\end{array}$ & 1992 ACCP/SCCM [1] & $\begin{array}{l}\text { Ang-2 higher in patients with sepsis than without sepsis } \\
\text { ( } 4.1 \text { vs. } 0.4 \mathrm{ng} / \mathrm{mL} ; P<0.01 \text { ) }\end{array}$ & $\begin{array}{l}\text { Higher Ang- } 2 \text { associated with ALI/ARDS }(P<0.001) \\
\text { and higher in ARDS than in ALI }(P>0.001) ; \\
\text { Independently associated with the severity of } \\
\text { pulmonary leak }(r=0.41 ; P=0.014) \text {. }\end{array}$ \\
\hline $\begin{array}{l}\text { Orfanos } \\
\text { et al., [38] }\end{array}$ & 2007 & 61 & ICU patients & 1992 ACCP/SCCM [1] & $\begin{array}{l}\text { Ang-2 higher in severe sepsis compared to patients } \\
\text { without SIRS or sepsis }(P<0.05 \text { by analysis of variance) }\end{array}$ & $\begin{array}{l}\text { Ang-2 levels correlated with levels of circulating } \\
\text { TNF }(P<0.05)\end{array}$ \\
\hline $\begin{array}{l}\text { Giamarellos- } \\
\text { Bourboulis } \\
\text { et al., [40] }\end{array}$ & 2008 & 60 & $\begin{array}{l}\text { Trauma patients admitted } \\
\text { to ICU (54) and healthy } \\
\text { controls (6) }\end{array}$ & 2003 ACCP/SCCM [2] & $\begin{array}{l}\text { Ang-2 higher in sepsis and severe sepsis than in healthy } \\
\text { controls, or trauma patients with sterile SIRS }(P<0.05) \text {; } \\
\text { Predictive of sepsis/severe sepsis }(P=0.017,0.002 \\
\text { respectively); Increases in serial Ang-2 predicted } \\
\text { development of sepsis }(P<0.05)\end{array}$ & Ang-2 correlated with 28-day survival $(P=0.015)$ \\
\hline $\begin{array}{l}\text { Kumpers } \\
\text { et al., [42] }\end{array}$ & 2008 & 72 & $\begin{array}{l}\text { Patients admitted to } \\
\text { medical ICU (43) and } \\
\text { healthy controls (29) }\end{array}$ & 2003 ACCP/SCCM [2] & $\begin{array}{l}\text { Ang-2 higher in septic patients than in patients without } \\
\text { sepsis ( } 16.5 \mathrm{vs} .2 .8 \mathrm{ng} / \mathrm{mL} ; P<0.001 \text { ); Not correlated } \\
\text { with severity of sepsis (median Ang-2 } 16.5 \text { vs. } 28.1 \mathrm{ng} / \\
\mathrm{mL} ; P=0.12 \text { ); }\end{array}$ & Ang-2 correlated with mortality $(P=0.001)$ \\
\hline $\begin{array}{l}\text { Davis et al., } \\
{[44]}\end{array}$ & 2010 & 124 & $\begin{array}{l}\text { Patients admitted to a } \\
\text { mixed ICU }\end{array}$ & 1992 ACCP/SCCM [1] & $\begin{array}{l}\text { Ang-2 higher in patients with severe sepsis compared to } \\
\text { patients with sepsis without organ failure and non- } \\
\text { septic controls ( } 12.4 \text { vs. } 6.1 \text { and } 2.7 \mathrm{ng} / \mathrm{mL} \text {, respectively; } \\
P<0.0001 \text { ). }\end{array}$ & Ang-2 not predictive of 28-day mortality $(P=0.32)$ \\
\hline $\begin{array}{l}\text { Siner et al., } \\
{[39]}\end{array}$ & 2009 & 66 & Patients admitted to ICU & 1992 ACCP/SCCM [1] & Ang-2 not correlated with severity of sepsis & Ang-2 correlated with mortality $(P=0.02)$ \\
\hline $\begin{array}{l}\text { Ricciuto } \\
\text { et al. [48] }\end{array}$ & 2011 & 70 & Patients with severe sepsis & 1992 ACCP/SCCM [1] & & $\begin{array}{l}\text { Admission levels of Ang- } 2 \text { and Ang- } 2 / \text { Ang- }^{-1} \text { ratio } \\
\text { were not associated with } 28 \text {-day mortality Serially } \\
\text { measured Ang-2 levels correlated directly with the } \\
\text { MOD score }(P=.003)\end{array}$ \\
\hline $\begin{array}{l}\text { Ebihara } \\
\text { et al. [49] }\end{array}$ & 2011 & 25 & $\begin{array}{l}25 \text { patients treated with } \\
\text { Polymyxin-B column } \\
\text { hemoperfusion } 11 \\
\text { developed ALI }\end{array}$ & 1992 ACCP/SCCM [1] & & $\begin{array}{l}\text { Positive correlation between Ang- } 1 \text { and } \mathrm{PaO} 2 / \mathrm{FiO} 2 \\
\text { ratio }(r=0.427 ; P<0.001) \text { Inverse correlation } \\
\text { between Ang- } 2 \text { and } \mathrm{PaO} 2 / \mathrm{FiO} 2 \text { ratio }(r=0.302 ; \\
P=0.003)\end{array}$ \\
\hline $\begin{array}{l}\text { Page et al., } \\
{[50]}\end{array}$ & 2011 & 37 & $\begin{array}{l}16 \text { invasive streptococcal } \\
\text { infection and toxic shock } \\
21 \text { invasive steptococcal } \\
\text { infection alone }\end{array}$ & $\begin{array}{l}\text { S. pyogenes isolated from } \\
\text { normally sterile site and } 2009 \\
\text { Consensus definition of } \\
\text { streptococcal toxic shock }\end{array}$ & $\begin{array}{l}\text { Ang-2:Ang-1 ratio increased in Streptococcal Toxic Shock } \\
\text { Syndrome compared to those with uncomplicated } \\
\text { invasive streptococcal infection }(P<0.05)\end{array}$ & \\
\hline $\begin{array}{l}\text { Kranidoti } \\
\text { et al., [41] }\end{array}$ & 2009 & 107 & $\begin{array}{l}\text { ICU patients with } \\
\text { Ventilator Associated } \\
\text { pneumonia (90) and } \\
\text { healthy controls (17) }\end{array}$ & 2003 ACCP/SCCM [1] & $\begin{array}{l}\text { Ang-2 higher in septic patients compared to healthy } \\
\text { controls. }(P<0.001)\end{array}$ & $\begin{array}{l}\text { Ang-2 correlated with mortality }(P<0.05) \text {; Ang-2 } \\
\text { levels greater than } 9.7 \mathrm{ng} / \mathrm{mL} \text { associated with } \\
\text { sepsis-related mortality }(\mathrm{OR}=3.3 ; P=0.033)\end{array}$ \\
\hline
\end{tabular}

ACCP, American College of Chest Physicians; ALI, Acute Lung Injury; APACHE II, Acute Physiology and Chronic Health Evaluation II; ARDS, Acute Respiratory Distress Syndrome; ED, emergency department; MOF, Multiple Organ Failure; SAPS, Simplified Acute Physiology Score; SCCM, Society of Critical Care Medicine; SIRS, systemic inflammatory response syndrome; SOFA, Sequential Organ Failure Assessment 
Table 2 Studies evaluating sICAM

\begin{tabular}{|c|c|c|c|c|c|c|}
\hline$\overline{\text { Study }}$ & Year & $\mathrm{N}$ & Population & $\begin{array}{l}\text { Standard Criteria for } \\
\text { SIRS/Sepsis }\end{array}$ & Associations with sepsis & Other outcomes \\
\hline Shapiro et al., [51] & 2010 & 221 & $\begin{array}{l}\text { ED patients with sepsis without organ } \\
\text { dysfunction (71), severe sepsis } \\
\text { without shock (66), septic shock (71), } \\
\text { and non-infected controls (13) }\end{array}$ & 1992 ACCP/SCCM [1] & $\begin{array}{l}\text { sICAM-1 elevated in septic shock compared } \\
\text { with non-infected controls }(P<0.05) \text {; }\end{array}$ & $\begin{array}{l}\text { sICAM-1 associated with increasing sepsis } \\
\text { severity } P<0.05 \text {; modest correlation with SOFA } \\
\text { and APACHE-II; predicts mortality and severe } \\
\text { sepsis (AUC of } 0.72 \text { ( } 95 \% \text { CI } 0.57 \text { to } 0.87), 0.61\end{array}$ \\
\hline
\end{tabular}

Schuetz et al., [52] 2011161 Patients with hypotension: 69 sepsis 35 cardiac 12 hemorrhagic 12 unknown

Hofer et al., [55]

2009147 Surgical ICU patients with severe sepsis (101) and major abdomina

surgery (28), and healthy controls (18)

Stief et al., [54]

200786 ICU patients with Sepsis (62), healthy controls (24)

Scherpereel et al., [53]

Kinoshita et al., [56] healthy controls (20)

abdominal infection admitted to abdominal infection admitted to
surgical ICU (47), healthy controls (9)

Paterson et al., [57] 200016 ICU patients with SIRS (10), healthy controls (6)

Weigand et al., [58] $199921 \quad$ Surgical ICU patients with septic shock (14), healthy controls (7)

Froon et al., [73] $1998 \quad 42 \quad$ ICU patients with sepsis and VAP

Kayal et al., [59]

199841 ICU patients with severe sepsis or septic shock (25), ICU controls (7). healthy controls (9)
Clinical classification based on clinical and microbiological data 2003 ACCP/SCCM [2]

ICAM-1 higher in sepsis compared to non-sepsis $(P<0.05)$

sICAM-1 higher in the septic group than postoperative and volunteer groups at diagnosis (444.7 ng/ml vs $213.7 \mathrm{ng} / \mathrm{ml}$ and $219.6 \mathrm{ng} / \mathrm{ml}$ respectively: $P<0.001)$

Clinical definition of sepsis

1992 ACCP/SCCM [1]

1992 ACCP/SCCM [1]

1992 ACCP/SCCM [1]

1992 ACCP/SCCM [1]

1992 ACCP/SCCM [1]

1992 ACCP/SCCM [1]

Higher in sepsis than controls $(2.56 \mathrm{ug} / \mathrm{ml}$ vs $0.19 \mathrm{ug} / \mathrm{ml} ; P<0.05$ )

SICAM-1 higher in sepsis compared to SIRS $P<$ 0.02

sICAM-1 higher in sepsis than healthy controls

sICAM-1 not reported in healthy controls

sICAM-1 significantly higher in sepsis than controls $(P<0.05)$

sICAM-1 higher in VAP patients complicated by severe sepsis or septic shock than other VAP patients, but statistical significance not achieved

sICAM-1 higher in septic patients than in noninfected ICU controls and healthy volunteers with $(P<0.0001)$; higher in septic shock than those MOF) without septic shock $(P<0.05)$
Not predictive of mortality at the time of diagnosis of sepsis, but non-survivors had trend to higher sICAM-1 levels at $48 \mathrm{~h}$ and $120 \mathrm{~h}$ (683.2 vs $434.1 \mathrm{ng} / \mathrm{ml}, P=0.067 ; 360.2$ vs 467.8 $\mathrm{ng} / \mathrm{ml}, P=0.083$, respectively) compared to survivors

sICAM-1 not predictive of mortality or severity of sepsis

Not correlated with mortality in those with ARDS; Higher in those with ARDS than those without $P<0.05$

Not correlated with mortality

sICAM-1 significantly higher in nonsurvivors than survivors, sensitivity and specificity for cutoff of $800 \mathrm{ng} / \mathrm{ml}$ was $74.1 \%$

Codictive of mortality, and correlates poorly with SAPS-II $(r=0.16, P=0.30)$

CAM-1 correlated with mortality; correlated 
Table 2 Studies evaluating sICAM (Continued)

\begin{tabular}{|c|c|c|c|c|c|c|}
\hline Boldt et al., [60] & 1997 & 30 & $\begin{array}{l}\text { Surgical ICU patients with post- } \\
\text { operative sepsis (30), healthy controls } \\
\text { (not stated) }\end{array}$ & $1992 \mathrm{ACCP}^{-\mathrm{SCCM}^{1}}$ & $\begin{array}{l}\text { sICAM-1 higher in septic patients than healthy } \\
\text { controls }\end{array}$ & $\begin{array}{l}\text { Higher in older than younger patients } P<0.05 \text {, } \\
\text { and tends to increase in older patients and } \\
\text { decrease in younger patients over time }\end{array}$ \\
\hline Egerer et al., [61] & 1997 & 24 & $\begin{array}{l}\text { ICU patients with infection (8), severe } \\
\text { sepsis (16) }\end{array}$ & 1992 ACCP/SCCM [1] & $\begin{array}{l}\text { sICAM-1 higher in severe sepsis compared with } \\
\text { patients with infection }(P>0.05)\end{array}$ & $\begin{array}{l}\text { Not correlated with mortality in patients with } \\
\text { severe sepsis }\end{array}$ \\
\hline Takakuwa et al., [62] & 1997 & 34 & $\begin{array}{l}\text { ICU admissions with sepsis (20), } \\
\text { trauma (14) }\end{array}$ & $\begin{array}{l}\text { Clinical definition of } \\
\text { SIRS and sepsis }\end{array}$ & $\begin{array}{l}\text { sICAM-1 level higher in septic than trauma } \\
\text { patients ( } 987.7 \text { vs } 472.1 \mathrm{ng} / \mathrm{ml} ; P=0.0002 \text { ) }\end{array}$ & $\begin{array}{l}\text { sICAM-1 correlated with endotoxin, TNF- } \alpha \text {, IL-6, } \\
\text { IL-8, Type II PLA2 (Type II phospholiaps A2), NO } \\
(P<0.05 \text { for all) }\end{array}$ \\
\hline Boldt et al., [63] & 1996 & 30 & $\begin{array}{l}\text { Surgical ICU patients with } \\
\text { postoperative sepsis (15), trauma (15) }\end{array}$ & 1992 ACCP/SCCM [1] & $\begin{array}{l}\text { slCAM-1 higher in sepsis than trauma }(1,266 \text { vs } \\
444 \mathrm{ng} / \mathrm{ml} ; P<0.01)\end{array}$ & \\
\hline Endo et al., [64] & 1996 & 28 & $\begin{array}{l}\text { ICU patients with sepsis with MOF (8), } \\
\text { sepsis without MOF (15), MOF } \\
\text { without sepsis (5) }\end{array}$ & $\begin{array}{l}\text { Clinical diagnosis of } \\
\text { sepsis }\end{array}$ & $\begin{array}{l}\text { sICAM-1 higher in septic patients with or } \\
\text { without MOF than patients with MOF but no } \\
\text { infection ( } 1103.3 \text { vs } 356.0 \mathrm{ng} / \mathrm{ml} \text {, and } 862.5 \text { vs } \\
356.0 \mathrm{ng} / \mathrm{ml} \text {, respectively, } P<0.05) \text { ) }\end{array}$ & $\begin{array}{l}\text { sICAM-1 level higher in septic patients with } \\
\text { MOF than those without }(P=0.0401)\end{array}$ \\
\hline Moss et al., [66] & 1996 & 55 & $\begin{array}{l}\text { ICU patients with sepsis (19), trauma } \\
\text { (36) controls (5) }\end{array}$ & $\begin{array}{l}\text { Clinical diagnosis of } \\
\text { sepsis }\end{array}$ & $\begin{array}{l}\text { sICAM- } 1 \text { higher in septic patients than trauma } \\
\text { and controls }(573 \text { vs } 148 \text { and } 235 \mathrm{ng} / \mathrm{ml} \text {, } \\
\text { respectively, } P<0.001)\end{array}$ & \\
\hline Nakae et al., [67] & 1996 & 34 & $\begin{array}{l}\text { ICU patients with sepsis (21), trauma } \\
\text { (13) }\end{array}$ & 1992 ACCP/SCCM [1] & $\begin{array}{l}\text { sICAM-1 higher in septic patients than in } \\
\text { trauma patients ( } 987 \mathrm{vs} 472 \mathrm{pg} / \mathrm{ml} ; P=0.0002 \text { ) }\end{array}$ & $\begin{array}{l}\text { sICAM-1 correlated with endotoxin, TNF-alpha } \\
\text { and IL-8 }(P<0.05 \text { for all })\end{array}$ \\
\hline Sessler et al., [68] & 1995 & 66 & $\begin{array}{l}\text { ICU patients with sepsis (25), SIRS } \\
\text { (25), ICU controls (4), healthy } \\
\text { volunteers (12) }\end{array}$ & 1992 ACCP/SCCM [1] & $\begin{array}{l}\text { sICAM- } 1 \text { higher in sepsis than ICU controls and } \\
\text { healthy controls }(1,259 \text { vs } 585 \mathrm{ng} / \mathrm{ml}, P<0.001 ; \\
1,259 \text { vs } 355 \mathrm{ng} / \mathrm{ml}, P<0.0001) ; \text { sICAM- } 1 \text { is } \\
\text { higher in SIRS than ICU controls and healthy } \\
\text { controls }(937 \mathrm{vs} 585 \mathrm{ng} / \mathrm{ml}, P<0.05 ; 937 \text { vs } 355 \\
\mathrm{ng} / \mathrm{ml}, P<0.001) \text {; higher in sepsis vs SIRS }(1,259 \\
\text { vs } 937 \mathrm{ng} / \mathrm{ml} ; P=0.12)\end{array}$ & $\begin{array}{l}\text { sICAM- } 1 \text { elevated with increasing severity of } \\
\text { illness: septic shock, severe sepsis and sepsis } \\
(1,551,796, \text { and } 542 \mathrm{ng} / \mathrm{ml} \text {, respectively, ANOVA } \\
P=0.017) \text {; correlated with cumulative MOF } \\
\text { score, shock severity score }(r=0.46, P=0.021 ; r \\
=0.50, P<0.009) ; \text { higher in nonsurvivors vs } \\
\text { survivors }(1,697 \text { vs } 854 \mathrm{ng} / \mathrm{ml} ; P=0.0096)\end{array}$ \\
\hline Cowley et al., [65] & 1994 & 125 & $\begin{array}{l}\text { ICU patients with sepsis (21), severe } \\
\text { sepsis (14), ICU controls (5), healthy } \\
\text { controls (85) }\end{array}$ & $\begin{array}{l}\text { Clinical definition of } \\
\text { SIRS and sepsis }\end{array}$ & $\begin{array}{l}\text { sICAM-1 higher in severe sepsis, uncomplicated } \\
\text { sepsis, and ICU controls than healthy controls } P \\
<0.05 \text {. }\end{array}$ & $\begin{array}{l}\text { sICAM-1 with no significant difference between } \\
\text { severe sepsis, uncomplicated sepsis and ICU } \\
\text { controls. Not correlated with mortality }\end{array}$ \\
\hline
\end{tabular}

ACCP, American College of Chest Physicians; ALI, Acute Lung Injury; APACHE II, Acute Physiology and Chronic Health Evaluation II; ARDS, Acute Respiratory Distress Syndrome; ED, emergency department; MOF, Multiple Organ Failure; SAPS, Simplified Acute Physiology Score; SCCM, Society of Critical Care Medicine; SIRS, Systemic Inflammatory Response Syndrome; SOFA, Sequential Organ Failure Assessment 
Multiple Organ Failure; SAPS, Simplified Acute Physiology Score; SCCM, Society of Critical Care Medicine; SIRS, Systemic Inflammatory Response Syndrome; SOFA, Sequential Organ Failure Assessment 


\begin{tabular}{|c|c|c|c|c|c|c|}
\hline Study & Year & $\mathbf{N}$ & Population & $\begin{array}{l}\text { Standard Criteria for } \\
\text { SIRS/Sepsis }\end{array}$ & Association with sepsis & Other outcomes \\
\hline Schuetz et al., [52] & 2011 & 161 & $\begin{array}{l}\text { Patients with hypotension: } 69 \\
\text { sepsis, } 35 \text { cardiac, } 12 \text { hemorrhagic, } \\
12 \text { unknown }\end{array}$ & $\begin{array}{l}\text { Clinical classification } \\
\text { based on clinical and } \\
\text { microbiological data }\end{array}$ & $\begin{array}{l}\text { E-selectin higher in sepsis compared to non- } \\
\text { sepsis }(P<0.05) \text { E-selectin independently } \\
\text { associated with sepsis after adjustment for age, } \\
\text { sex, blood pressure and mortality ( } P=0.001) \text { with } \\
\text { AUC of } 0.74 \text { for discrimination of sepsis and non- } \\
\text { sepsis }\end{array}$ & \\
\hline Shapiro et al., [51] & 2010 & 221 & $\begin{array}{l}\text { ED patients with sepsis without } \\
\text { organ dysfunction ( } 71) \text {, severe } \\
\text { sepsis without shock (66), septic } \\
\text { shock (71), and non-infected } \\
\text { controls (13) }\end{array}$ & 1992 ACCP/SCCM [1] & $\begin{array}{l}\text { sE-selectin-1 levels elevated in septic shock } \\
\text { compared with non-infected controls }\end{array}$ & $\begin{array}{l}\text { SE-selectin-1 associated with sepsis severity } P< \\
0.001 \text {; predicts mortality and severe sepsis (AUC } \\
\text { of } 0.65 \text { ( } 95 \% \text { Cl } 0.49 \text { to } 0.82) \text { and } 0.71(95 \% \mathrm{Cl} \\
0.64 \text { to } 0.78) \text { respectively) }\end{array}$ \\
\hline Stief et al., [54] & 2007 & 86 & $\begin{array}{l}\text { ICU patients with Sepsis (62), } \\
\text { healthy controls (24) }\end{array}$ & $\begin{array}{l}\text { Clinically diagnosed } \\
\text { sepsis }\end{array}$ & $\begin{array}{l}\text { sE-selectin-1 elevated in sepsis compared to } \\
\text { reference value }(190 \mathrm{ng} / \mathrm{ml} \text { vs } 55 \mathrm{ng} / \mathrm{ml} ; P< \\
0.05))\end{array}$ & \\
\hline Kinoshita et al., [56] & 2002 & 56 & $\begin{array}{l}\text { Gram negative sepsis from intra- } \\
\text { abdominal infection admitted to } \\
\text { surgical ICU (47), healthy controls } \\
(9)\end{array}$ & 1992 ACCP/SCCM [1] & $\begin{array}{l}\text { sE-selectin-1 does not differentiate between } \\
\text { ARDS from non ARDS }\end{array}$ & Not predictive of mortality in those with ARDS \\
\hline Geppert et al., [74] & 2000 & 32 & $\begin{array}{l}\text { ICU patients on day two post } \\
\text { successfulCPR (25), non-critically ill } \\
\text { controls (7) }\end{array}$ & 1992 ACCP/SCCM [1] & $\begin{array}{l}\text { sE-selectin-1 higher in SIRS compared to controls } \\
(96.2 \mathrm{ng} / \mathrm{ml} \text { vs } 42.8 \mathrm{ng} / \mathrm{ml} ; P=0.23) \text {, but does } \\
\text { not differentiate patients with SIRS vs patients } \\
\text { without SIRS }\end{array}$ & $\begin{array}{l}\text { Higher in non-survivors than survivors (114.2 ng/ } \\
\mathrm{ml} \text { vs } 85.7 \mathrm{ng} / \mathrm{ml} ; P=0.025 \text { ) }\end{array}$ \\
\hline $\begin{array}{l}\text { Osmanovic et al., } \\
\text { [72] }\end{array}$ & 2000 & 27 & $\begin{array}{l}\text { ICU patients with sepsis with MOF } \\
\text { (9), healthy controls (18) }\end{array}$ & $\begin{array}{l}\text { Clinical definition of } \\
\text { sepsis }\end{array}$ & $\begin{array}{l}\text { sE-selectin-1 higher in sepsis compared to } \\
\text { healthy controls ( } 118 \text { vs } 28.5 \mathrm{ng} / \mathrm{ml} ; P<0.001)\end{array}$ & \\
\hline Hynninen et al., [70] & 1999 & 20 & $\begin{array}{l}\text { ICU patients with severe sepsis } \\
\text { (11), severe acute pancreatitis (9) }\end{array}$ & 1992 ACCP/SCCM [1] & $\begin{array}{l}\text { SE-selectin does not differentiation between } \\
\text { those with severe acute pancreatitis and severe } \\
\text { sepsis }\end{array}$ & $\begin{array}{l}\text { Higher in those with higher SOFA scores (SOFA } \geq \\
10, P=0.043 \text { ), but not correlated with mortality }\end{array}$ \\
\hline Presterl et al., [69] & 1999 & 40 & $\begin{array}{l}\text { ICU patients with candida (20) } \\
\text { and bacterial sepsis (20) }\end{array}$ & 1992 ACCP/SCCM [1] & $\begin{array}{l}\text { SE-selectin-1 lower in patients with Candida } \\
\text { sepsis than bacterial sepsis }(P<0.05) \text { on Day } 1\end{array}$ & Higher in non-survivors \\
\hline Takala et al., [71] & 1999 & 76 & $\begin{array}{l}\text { Hospitalized patients with sepsis } \\
\text { with organ failure (8) and without } \\
\text { organ failure (12); healthy controls } \\
\text { (56) }\end{array}$ & 1992 ACCP/SCCM [1] & $\begin{array}{l}\text { sE-selectin-1 level elevated in septic patients } \\
\text { compared to healthy adults } P<0.001\end{array}$ & Not correlated with organ failure \\
\hline Weigand et al., [58] & 1999 & 21 & $\begin{array}{l}\text { Surgical ICU patients with septic } \\
\text { shock (14), healthy controls (7) }\end{array}$ & 1992 ACCP/SCCM [1] & $\begin{array}{l}\text { sE-selectin-1 higher in sepsis than healthy } \\
\text { controls }(P<0.05)\end{array}$ & Not predictive of mortality or severity of disease \\
\hline Froon et al., [73] & 1998 & 42 & ICU patients with sepsis and VAP & 1992 ACCP/SCCM [1] & $\begin{array}{l}\text { sE-selectin-1 higher in patients with severe sepsis } \\
\text { or septic shock than other VAP patients, but } \\
\text { statistical significance not achieved }\end{array}$ & $\begin{array}{l}\text { Day } 2 \text { sE-selectin- } 1 \text { higher in nonsurvivors than } \\
\text { survivors (114.3 vs } 67.0 \mathrm{ng} / \mathrm{ml} ; P=0.04) ; \\
\text { Correlates poorly with SAPSII }(r=0.18, P=0.25 \text { ) }\end{array}$ \\
\hline Kayal et al., [59] & 1998 & 41 & $\begin{array}{l}\text { ICU patients with severe sepsis or } \\
\text { septic shock ( } 25) \text {, ICU controls ( } 7 \text { ), } \\
\text { healthy controls (9) }\end{array}$ & 1992 ACCP/SCCM [1] & $\begin{array}{l}\text { sE-selectin-1 higher in septic patients than } \\
\text { noninfected ICU controls and healthy volunteers } \\
(p<0.0001) \text {; higher in those with septic shock } \\
\text { than those without }(p<0.05)\end{array}$ & $\begin{array}{l}\text { SE-selectin- } 1 \text { higher in nonsurvivors than survivors } \\
\text { on day } 0 \text { ( } 286 \mathrm{vs} 195 \mathrm{ng} / \mathrm{ml} ; P<0.05) \text {, but } \\
\text { decreases after Day } 3 \text { of sepsis to reach a level } \\
\text { similar to that of survivors Day } 14 \text {; correlated with } \\
\text { SAPS and MOF score ( } r=0.45, P<0.05 \text { for MOF) }\end{array}$ \\
\hline
\end{tabular}


Knapp et al., [78] $199854 \quad$ Patients with sepsis (28 gram positive, 11 gram negative), 15 healthy controls

Boldt et al., [60]

199730 Surgical ICU patients with postoperative sepsis (30), healthy controls (not stated)

Cummings et al., (44), ICU controls (8)
1997119 ICU patients with sepsis (67), SIRS

1992 ACCP/SCCM [1] controls $\mathrm{p}<0.05$

1992 ACCP/SCCM [1]

sE-selectin-1 higher in septic patients than healthy controls

1992 ACCP/SCCM [1]

SE-selectin-1 higher in culture positive sepsis than culture negative sepsis, SIRS and ICU controls ( 15.39 vs $4.87,2.33$, and $1.97 \mathrm{ng} / \mathrm{ml}$, respectively; $P<0.0001$

1992 ACCP/SCCM [1] Higher in patients with severe sepsis and MOF than those with infection alone $(P<0.05)$ severe sepsis (16)

Egerer et al., [61]

Takakuwa et al., [62] $1997 \quad 34$ ICU admissions with sepsis (20), trauma (14)

Boldt et al., [63]

199630 Surgical ICU patients with postoperative sepsis (15), trauma (15)

Endo et al., [64]

199628 ICU patients with sepsis with MOF (8), sepsis without MOF (15), MOF without sepsis (5)

Moss et al., [66]

199655 ICU patients with sepsis (19), trauma (36) controls (5)

Simons et al., [75]

Cowley et al., [65]

1994125 ICU patients with sepsis (21) healthy controls (85)

Newman et al., [80]

199388 ICU patients with sepsis with
positive blood cultures (17), healthy controls (71)
No Standard Definition sE-selectin-1 higher in sepsis than trauma (287.9 vs $195.0 \mathrm{ng} / \mathrm{ml} ; P=0.0055$

1992 ACCP/SCCM [1] SE-selectin-1 higher in sepsis than trauma (340 vs $57.9 \mathrm{ng} / \mathrm{ml} ; P<0.05$

sE-selectin-1 higher in septic patients with or without MOF than patients with MOF but no infection (345.2 vs $121.8 \mathrm{ng} / \mathrm{ml}, P=0.0016 ; 266.2$ vs $121.8 \mathrm{ng} / \mathrm{ml}, P=0.0054$

Clinical diagnosis of Higher in sepsis than trauma and controls (573 vs sepsis

Not specified 148 and $235 \mathrm{ng} / \mathrm{ml}$, respectively, $P<0.001$ )

sE-selectin-1 higher in patients who subsequently sE-selectin-1 higher in non-survivors than developed infection, organ dysfunction, or both, survivors $(P=0.0018)$

by 36 h. $P=0.08$

Clinical definition of sE-selectin higher in sepsis than controls $(P<$ 0.01).

Clinical definition of sepsis

Higher in septic shock than controls (23.3 vs 0.92 $\mathrm{ng} / \mathrm{ml} ; P<0.05)$; not elevated in uncomplicated sepsis compared to controls Type II PLA2, sICAM-1 $(P<0.005$ for all)

$266.2 \mathrm{ng} / \mathrm{ml} ; P=0.2939$ )

survivors $(P=0.0018)$

SE-selectin-1 higher in severe sepsis than 0.001). Not correlated with mortality
sE-selectin-1 higher in nonsurvivors than survivors of gram positive sepsis on day 0,4 and 7 (175 vs $85 \mathrm{ng} / \mathrm{ml}, P<0.01 .155 .7$ vs $78.8 \mathrm{ng} / \mathrm{ml}, P<0.05$ 180 vs $76.1 \mathrm{ng} / \mathrm{ml}, P<0.001$, respectively); does not differentiate gram positive from gram negative infections.

Higher in older than younger patients $P<0.05$, and tends to increase in older patients and decrease in younger patients over time

Day 1 levels higher for nonsurvivors than survivors (10.61 vs $4.35 \mathrm{ng} / \mathrm{ml}$ of log transformed mean sE-selectin-1; $P<0.05$ ); sE-selectin-1 correlates strongly to the degree of hemodynamic compromise $(P<0.0001)$, and moderately with the peak MOF score $(r=0.30, P$ $=0.001)$

Higher in nonsurvivors than survivors on Day $7-8$ $P<0.05$

E-selectin-1 level correlated with TNF- $\alpha, \|-8$

sE-selectin-1 did not differ significantly between septic patients with and without MOF (345.2 vs uncomplicated sepsis on presentation $(P<0.01)$ and more pronounced with peak values $(P<$

ACCP, American College of Chest Physicians; ALI, Acute Lung Injury; APACHE II, Acute Physiology and Chronic Health Evaluation II; ARDS, Acute Respiratory Distress Syndrome; ED, emergency department; MOF, Multiple Organ Failure; SAPS, Simplified Acute Physiology Score; SCCM, Society of Critical Care Medicine; SIRS, Systemic Inflammatory Response Syndrome; SOFA, Sequential Organ Failure Assessment 
Table 5 Studies evaluating Endocan

\begin{tabular}{|c|c|c|c|c|c|c|}
\hline Study & Year & $\mathrm{N}$ & Population & $\begin{array}{l}\text { Standard } \\
\text { Criteria for } \\
\text { SIRS/Sepsis } \\
\end{array}$ & Association with sepsis & Other outcomes \\
\hline $\begin{array}{l}\text { Scherpereel } \\
\text { et al., [53] }\end{array}$ & 2006 & 90 & $\begin{array}{l}\text { ICU patients } \\
\text { with sepsis (63), } \\
\text { SIRS (7), healthy } \\
\text { controls (20) }\end{array}$ & $\begin{array}{l}1992 \text { ACCP/ } \\
\text { SCCM [1] }\end{array}$ & $\begin{array}{l}\text { Higher in sepsis than SIRS or healthy } \\
\text { controls ( } 2.71 \text { vs } 0.77 \text { and } 0.68 \mathrm{ng} / \mathrm{ml} \text {; } \\
P<0.001) ; \text { higher in septic shock than } \\
\text { severe sepsis and uncomplicated sepsis } \\
(6.11 \text { vs } 1.97 \text { and } 1.95 \mathrm{ng} / \mathrm{ml} \text {; } \\
P<0.05, P<0.02)\end{array}$ & $\begin{array}{l}\text { Endocan on ICU admission higher in } \\
\text { nonsurvivors than patients still alive after } \\
10 \text { days ( } 6.98 \text { vs } 2.54 \mathrm{ng} / \mathrm{ml} ; P<0.01 \text { ), } \\
\text { using a cutoff of } 6.2 \mathrm{ng} / \mathrm{ml} \text {, sensitivity and } \\
\text { specificity are } 75 \% \text { and } 84 \% \text { respectively. }\end{array}$ \\
\hline $\begin{array}{l}\text { Bechard } \\
\text { et al., [23] }\end{array}$ & 2000 & 28 & $\begin{array}{l}\text { Patients with } \\
\text { septic shock (8), } \\
\text { healthy controls } \\
(20)\end{array}$ & $\begin{array}{l}1992 \text { ACCP/ } \\
\text { SCCM [1] }\end{array}$ & $\begin{array}{l}\text { Higher in septic shock than healthy } \\
\text { controls ( } 7.815 \text { vs } 1.081 \mathrm{ng} / \mathrm{ml} ; P=0.0173 \text { ) }\end{array}$ & \\
\hline
\end{tabular}

ACCP, American College of Chest Physicians; ALI, Acute Lung Injury; APACHE II, Acute Physiology and Chronic Health Evaluation II; ARDS, Acute Respiratory Distress Syndrome; ED, emergency department; MOF, Multiple Organ Failure; SAPS, Simplified Acute Physiology Score; SCCM, Society of Critical Care Medicine; SIRS, Systemic Inflammatory Response Syndrome; SOFA, Sequential Organ Failure Assessment

correlated with mortality $[55,58,59,68,77]$, but six studies found no such correlation $[53,56,57,61,65,73]$. One study found a trend towards increased mortality with increasing sICAM-1 levels over time [55].

Two studies evaluated the discriminative characteristics of sICAM-1 [51,58]. Weigand et al. reported that a sICAM-1 threshold of $800 \mathrm{ng} / \mathrm{ml}$ could differentiate survivors from non-survivors with a sensitivity and specificity of $74.1 \%$, although this value was derived from a small sample of 14 post-surgical patients with relatively high mortality (50\%) [58]. Shapiro reported on a group of 221 patients presenting to the emergency department with suspected infections, of which 208 had sepsis of varying severity. The presenting sICAM-1 value predicted mortality with an area under the receiver operating characteristic (ROC) curve of 0.72 (95\% CI (0.57 to 0.870$)$ ). However, a cutoff value was not reported [77].

Several studies reported moderate to poor correlation of sICAM-1 with the degree of severity of illness or number of organ failures as defined by APACHE II, SOFA, Multiple Organ Failure Score and Simplified Acute Physiology Score [59,68,73,77].

One study reported varying kinetics of sICAM-1 according to age: In 30 patients with postoperative sepsis, Boldt et al. reported that older patients had higher sICAM-1 levels than younger patients $(P<0.05)$, and sICAM-1 tended to increase over time in older patients while decreasing over time in younger patients [60].

\section{Soluble VCAM-1 (sVCAM-1)}

We identified 12 studies evaluating sVCAM-1 (see Table 3-Studies Evaluating sVCAM-1) in sepsis. These studies evaluated sVCAM-1 in emergency department patients [51], postoperative patients [55,63], patients admitted to ICU [56,62], critically-ill trauma patients [60] and patients with sepsis $[64,65,69,78]$. Three studies compared sVCAM-1 levels with healthy control groups $[55,65,78]$.

\section{Association with sepsis}

Six studies reported that sVCAM-1 levels were significantly greater in patients with sepsis than in healthy controls [65,78], trauma patients [62,63], non-infected patients [77] and patients with multiple organ failure due to causes other than sepsis [64]. Four studies reported that sVCAM-1 levels effectively differentiated septic from non-septic patients [62-64,77], but one study reported sVCAM-1 levels were not significantly different between septic patients, postoperative patients and healthy controls [55]. One study reported higher sVCAM-1 levels in patients with shock due to sepsis compared to other forms of shock [52].

Three studies attempted to correlate sVCAM-1 with increasing sepsis severity $[64,65,77]$. Shapiro et al. found a moderate degree of correlation with severe sepsis with an area under the ROC curve of 0.60 (95\% CI 0.52 to 0.69) [77]. Cowley et al. reported that baseline and peak values of sVCAM-1 were higher in ICU patients with severe sepsis than in uncomplicated sepsis [65]. Conversely, another study reported that sVCAM-1 was not different in septic patients with or without organ failure [64].

\section{Association with clinical outcome}

Six of the 10 identified studies examined mortality outcomes, with 2 studies reporting an association between higher sVCAM-1 levels and mortality [55,77], and 4 studies showing no significant correlation with mortality in patients with ARDS [56], gram-positive sepsis [78], and septic patients admitted to ICU $[65,69]$. Hofer et al. found no correlation between baseline sVCAM-1 and mortality in septic patients but reported significantly higher sVCAM-1 levels at 48 and 120 hours in non-survivors compared to survivors. 
Only one study addressed correlation of sVCAM-1 with clinical severity scores, and reported modest correlation with SOFA and APACHE II [77].

Two studies reported variability of SVCAM-1 in sepsis across different patient populations [64,69]. Presterl et $a l$. investigated the difference of sVCAM-1 level in Candida sepsis compared to bacterial sepsis, and found that sVCAM-1 was higher in Candida sepsis at days 1, 7 and 14 [69]. Similar to sICAM-1, Endo et al. found higher sVCAM-1 levels with increasing age, and observed that the dynamics of serial sVCAM-1 were different in patients stratified by age. Specifically, sVCAM-1 values increased over the course of sepsis time in older patients and decreased in younger patients [64].

One study found that SVCAM-1 was not associated with left ventricular size or function in patients with sepsis or septic shock [76].

\section{Soluble E-selectin}

Twenty-three studies were identified that evaluated sEselectin as a biomarker in sepsis (see Table 4-Studies Evaluating sE-selectin-1).

\section{Association with sepsis}

The majority of identified studies reported higher levels of sE-selectin in sepsis compared to healthy controls or other patient groups without sepsis. Ten studies specifically reported significantly elevated sE-selectin levels in sepsis when compared with healthy controls [54,58,59,65,66,71,72,78-80]. Geppert et al. reported higher sE-selectin levels in patients with SIRS following cardiopulmonary resuscitation compared to controls [74]. sE-selectin was also reported to be significantly higher in septic patients compared to trauma patients $[62,63,66]$, ICU controls [59,79], patients with infection but without systemic sepsis [61,77], patients with shock from other causes [52], and patients with multiple organ failure without infection [64]. Hynninen et al. concluded that $\mathrm{sE}$-selectin values were not statistically different in patients with severe sepsis from those with severe acute pancreatitis [70].

\section{Association with clinical outcome}

The reported association of $\mathrm{sE}$-selectin and disease severity has been inconsistent. Five studies showed a correlation between the marker and increasing sepsis severity $[59,61,65,77,79]$, although three studies did not find a significant correlation [64,71,73].

Thirteen of the identified studies evaluated the association between sE-selectin and mortality, with nine studies reporting a significant positive correlation [59,61,69,73-75,77-79] and four studies reporting no correlation [56,58,65,70]. Among the studies reporting positive association, there was significant heterogeneity in the strength and type of association. One study of ICU patients with severe sepsis and septic shock reported that baseline sE-selectin-1 levels were higher in non-survivors than survivors, but the difference existed only for the first three days of sepsis [59]. In contrast, two other studies demonstrated a more persistent divergence of sE-selectin-1 between survivors and non-survivors of sepsis: Knapp et al. reported that sE-selectin-1 remained significantly elevated in non-survivors compared to survivors throughout the first seven days of sepsis [78], while Egerer reported that $\mathrm{sE-selectin} \mathrm{peaked}$ in survivors of sepsis on the second day and decreased thereafter, whereas it continued to rise in patients who subsequently died [61]. One other study found that $\mathrm{sE}-$ selectin-1 predicted mortality in patients presenting to the emergency department with suspected infections, with an area under the ROC curve of 0.65 [51].

Only a few studies examined correlation between sEselectin-1 and clinical severity of illness scores, and none found strong correlations. Shapiro et al. showed that sE-selectin correlated modestly with SOFA and APACHE-II [51]. Hynnien et al. reported that levels of sE-selectin were higher in patients with a SOFA score $\geq$ 10 compared to individuals with a score less than 10 [70]. sE-Selectin was also reported to correlate moderately or poorly with SAPSII $[59,73]$ and MOF score $[59,79]$.

Three studies evaluated variability in sE-selectin levels in different patient groups [60,69,79]. Boldt et al. showed sE-selectin levels in septic patients increased across age groups [60]. Cummings et al. showed higher levels in bacteremic sepsis than in non-bacteremic sepsis [79], and Presterl et al. found higher levels of sE-selectin in bacterial sepsis than in Candida sepsis [69].

\section{Endocan}

Two prospective observational studies were identified evaluating endocan as a biomarker in sepsis $[23,53]$ (see Table 5-Studies Evaluating Endocan).

\section{Association with sepsis}

Both studies reported that serum endocan was increased in septic patients. Schepereel et al. reported in their prospective study that endocan levels were higher in patients with sepsis than in patients with SIRS or healthy controls [53]. Bechard et al. showed that endocan levels were higher in patients with septic shock than in healthy controls [23].

\section{Association with clinical outcome}

Scherpereel et al. reported that mean endocan levels were higher in patients with septic shock than in patients with severe sepsis or sepsis. Furthermore, endocan levels measured at ICU admission were higher in non-survivors than in patients who were alive at 10 days. Using a threshold of $6.2 \mathrm{ng} / \mathrm{ml}$, the sensitivity and specificity of endocan for predicting mortality were $75 \%$ and $84 \%$ respectively [53]. 
Table 6 Studies evaluating VEGF

\begin{tabular}{|c|c|c|c|c|c|c|}
\hline Study & Year & $\mathrm{N}$ & Population & $\begin{array}{l}\text { Standard } \\
\text { criteria for SIRS/ } \\
\text { sepsis }\end{array}$ & Association with sepsis & Other outcomes \\
\hline $\begin{array}{l}\text { Shapiro } \\
\text { et al., [77] }\end{array}$ & 2008 & 83 & $\begin{array}{l}\text { ED patients with septic shock } \\
\text { (17), suspected infection } \\
\text { without shock (66), and non- } \\
\text { infected controls }\end{array}$ & $\begin{array}{l}\text { Suspected } \\
\text { infection based } \\
\text { on treating } \\
\text { clinician }\end{array}$ & $\begin{array}{l}\text { VEGF levels higher in septic shock } \\
\text { and infected patients without shock } \\
\text { compared with non-infected } \\
\text { controls }(P<0.01)\end{array}$ & $\begin{array}{l}\text { VEGF correlated with APACHE- } \| \\
\text { score at presentation }(P=0.01)\end{array}$ \\
\hline $\begin{array}{l}\text { Karlsson } \\
\text { et al., [82] }\end{array}$ & 2008 & 280 & $\begin{array}{l}\text { Septic ICU patients ( } 250) \text { and } \\
\text { healthy controls (30) }\end{array}$ & $\begin{array}{l}1992 \text { ACCP/ } \\
\text { SCCM [1] }\end{array}$ & $\begin{array}{l}\text { VEGF levels higher in severe sepsis } \\
\text { compared with healthy controls at } 0 \\
\text { and } 72 \mathrm{~h}(P=0.029,0.003 \\
\text { respectively) }\end{array}$ & $\begin{array}{l}\text { VEGF lower in non-survivors at } \\
0 \text { and } 72 \mathrm{~h}(P=0.012,0.009, \\
\text { respectively), no correlation } \\
\text { with SOFA scores }\end{array}$ \\
\hline $\begin{array}{l}\text { Kumpers } \\
\text { et al., [42] }\end{array}$ & 2008 & 72 & $\begin{array}{l}\text { Medical ICU (43) and healthy } \\
\text { controls (29) }\end{array}$ & $\begin{array}{l}2003 \text { ACCP/ } \\
\text { SCCM [2] }\end{array}$ & $\begin{array}{l}\text { VEGF levels lower in non-septic and } \\
\text { septic patients compared with } \\
\text { healthy controls }(P<0.0001)\end{array}$ & $\begin{array}{l}\text { No association with severity of } \\
\text { sepsis }\end{array}$ \\
\hline $\begin{array}{l}\text { Van der } \\
\text { Heijden } \\
\text { et al., [45] }\end{array}$ & 2008 & 112 & $\begin{array}{l}\text { Mechanically ventilated } \\
\text { patients with sepsis (24) and } \\
\text { without (88) }\end{array}$ & $\begin{array}{l}1992 \text { ACCP/ } \\
\text { SCCM [1] }\end{array}$ & $\begin{array}{l}\text { VEGF levels higher in patients with } \\
\text { sepsis than without sepsis ( } 63.6 \text { vs } \\
20.7 \mathrm{pg} / \mathrm{ml}, P=0.012 \text { ) }\end{array}$ & $\begin{array}{l}\text { VEGF trended higher in } \\
\text { patients compared with } \\
\text { controls }(P=0.268) \text {; No } \\
\text { association with incidence of } \\
\text { ALI/ARDS }\end{array}$ \\
\hline $\begin{array}{l}\text { Van der Flier } \\
\text { et al., [83] }\end{array}$ & 2005 & 58 & $\begin{array}{l}\text { Severe sepsis (18) and healthy } \\
\text { controls (40) }\end{array}$ & $\begin{array}{l}1992 \text { ACCP/ } \\
\text { SCCM [1] }\end{array}$ & $\begin{array}{l}\text { VEGF levels elevated in sepsis } \\
\text { compared with healthy controls ( } 134 \\
\text { vs } 55 \mathrm{pg} / \mathrm{ml}, P<0.001 \text { ) }\end{array}$ & $\begin{array}{l}\text { VEGF correlated with mortality } \\
(P=0.018)\end{array}$ \\
\hline $\begin{array}{l}\text { Yang et al., } \\
{[101]}\end{array}$ & 2011 & 101 & $\begin{array}{l}81 \text { pneumonia and septic } \\
\text { shock } 20 \text { pneumonia without } \\
\text { organ dysfunction }\end{array}$ & $\begin{array}{l}1992 \text { ACCP/ } \\
\text { SCCM [1] }\end{array}$ & $\begin{array}{l}\text { VEGF levels lower in septic shock vs. } \\
\text { pneumonia }(P=0.005)\end{array}$ & $\begin{array}{l}\text { Day } 1 \text { VEGF did not } \\
\text { discriminate survivors from } \\
\text { non-survivors }(P=0.46)\end{array}$ \\
\hline $\begin{array}{l}\text { Rafat et al., } \\
{[84]}\end{array}$ & 2007 & 62 & $\begin{array}{l}\text { Medical ICU with sepsis (32), } \\
\text { without sepsis (15), and } \\
\text { healthy controls (15) }\end{array}$ & $\begin{array}{l}1992 \text { ACCP/ } \\
\text { SCCM [1] }\end{array}$ & $\begin{array}{l}\text { VEGF levels elevated in septic } \\
\text { compared with non-septic patients } \\
(1,351 \text { vs } 477 \mathrm{pg} / \mathrm{ml}, P<0.01)\end{array}$ & $\begin{array}{l}\text { VEGF not correlated with } \\
\text { mortality }(P<0.48)\end{array}$ \\
\hline
\end{tabular}

ACCP, American College of Chest Physicians; ALI, Acute Lung Injury; APACHE II, Acute Physiology and Chronic Health Evaluation II; ARDS, Acute Respiratory Distress Syndrome; ED, emergency department; MOF, Multiple Organ Failure; SAPS, Simplified Acute Physiology Score; SCCM, Society of Critical Care Medicine; SIRS, Systemic Inflammatory Response Syndrome; SOFA, Sequential Organ Failure Assessment

\section{Mediators of permeability and vasomotor tone}

We identified seven studies that examined soluble VEGF (see Table 6-Studies evaluating VEGF), two studies examining soluble FLT (Table 7-Studies Evaluating sFLT) and four studies examining endothelin-1 as biomarkers in sepsis (see Table 8-Studies Evaluating Endothelin-1). All but two were prospective studies, with two secondary analyses of previously conducted cohort studies $[45,81]$. Patients recruited were emergency room patients with suspected infection [51,77] or ICU patients [42,45,51,81-88].

Table 7 Studies evaluating sFLT

\begin{tabular}{|c|c|c|c|c|c|c|}
\hline Study & Year & $\mathbf{N}$ & Population & $\begin{array}{l}\text { Standard criteria } \\
\text { for SIRS/sepsis }\end{array}$ & Association with sepsis & Other outcomes \\
\hline $\begin{array}{l}\text { Schuetz } \\
\text { et al., [52] }\end{array}$ & 2011 & 161 & $\begin{array}{l}\text { Patients with hypotension: } 69 \\
\text { sepsis, } 35 \text { cardiac, } 12 \\
\text { hemorrhagic, } 12 \text { unknown }\end{array}$ & $\begin{array}{l}\text { Clinical classification } \\
\text { based on clinical } \\
\text { and microbiological } \\
\text { data }\end{array}$ & $\begin{array}{l}\text { sFlt-1 higher in sepsis compared } \\
\text { to non-sepsis }(P<0.05) \text { SFlt- } 1 \\
\text { independently associated with } \\
\text { sepsis after adjustment for age, } \\
\text { sex, blood pressure and mortality } \\
(P=0.03) \text { with AUC } 0.70 \text { for } \\
\text { discrimination of sepsis from } \\
\text { non-sepsis }\end{array}$ & \\
\hline $\begin{array}{l}\text { Shapiro } \\
\text { et al., [77] }\end{array}$ & 2008 & 83 & $\begin{array}{l}\text { ED patients with septic shock } \\
(17) \text {, suspected infection } \\
\text { without shock (66), and non- } \\
\text { infected controls }\end{array}$ & $\begin{array}{l}\text { Suspected infection } \\
\text { based on treating } \\
\text { clinician }\end{array}$ & $\begin{array}{l}\text { sFLT levels elevated with } \\
\text { worsening disease: non-infected, } \\
\text { suspected infection without } \\
\text { shock, septic shock }(159,386 \text { and } \\
551 \mathrm{ng} / \mathrm{dL} \text {, respectively, } P<0.01)\end{array}$ & $\begin{array}{l}\text { sFLT correlated with APACHE-II, } \\
\text { SOFA scores upon presentation } \\
\text { and at } 24 \mathrm{~h}(P<0.05 \text { for all) }\end{array}$ \\
\hline $\begin{array}{l}\text { Shapiro } \\
\text { et al., [51] }\end{array}$ & 2010 & 221 & $\begin{array}{l}\text { ED patients with sepsis } \\
\text { without organ dysfunction } \\
(71) \text {, severe sepsis without } \\
\text { shock (66), septic shock (71), } \\
\text { and non-infected controls (13) }\end{array}$ & 1992 ACCP/SCCM [1] & $\begin{array}{l}\text { sFLT levels elevated in septic } \\
\text { shock compared with non- } \\
\text { infected controls ( } 243 \text { vs } 41 \text { ng/ } \\
\mathrm{ml}, P<0.001 \text { ) }\end{array}$ & $\begin{array}{l}\text { sFLT correlated with SOFA, } \\
\text { APACHE-II, lactate; Predicted } \\
\text { severe sepsis and mortality (AUC } \\
\text { of } 0.82(95 \% \mathrm{Cl} 0.76 \text { to } 0.88) \text {, } \\
0.91(95 \% \mathrm{Cl} 0.87 \text { to } 0.95))\end{array}$ \\
\hline
\end{tabular}

ACCP, American College of Chest Physicians; ALI, Acute Lung Injury; APACHE II, Acute Physiology and Chronic Health Evaluation II; ARDS, Acute Respiratory Distress Syndrome; ED, emergency department; MOF, Multiple Organ Failure; SAPS, Simplified Acute Physiology Score; SCCM, Society of Critical Care Medicine; SIRS, Systemic Inflammatory Response Syndrome; SOFA, Sequential Organ Failure Assessment 
Table 8 Studies evaluating Endothelin-1

\begin{tabular}{|c|c|c|c|c|c|c|}
\hline Study & Year & $\mathbf{N}$ & Population & $\begin{array}{l}\text { Standard criteria for } \\
\text { SIRS/sepsis }\end{array}$ & Association with sepsis & Other Outcomes \\
\hline $\begin{array}{l}\text { Schuetz } \\
\text { et al., [81] }\end{array}$ & 2007 & 95 & $\begin{array}{l}\text { Consecutive ICU } \\
\text { admissions with SIRS, } \\
\text { sepsis, septic shock }\end{array}$ & 1992 ACCP/SCCM [1] & $\begin{array}{l}\text { Endothelin-1 rises with sepsis, } \\
\text { septic shock, compared with SIRS } \\
(64.3,131.6,23.1 \mathrm{pmol} / \mathrm{L} \text {, } \\
\text { respectively; } P<0.01 \text { between SIRS } \\
\text { and sepsis, } P<0.05 \text { between sepsis } \\
\text { and septic shock) }\end{array}$ & $\begin{array}{l}\text { Endothelin-1 not correlated with } \\
\text { mortality }(p=0.87)\end{array}$ \\
\hline $\begin{array}{l}\text { Piechota } \\
\text { et al., [85] }\end{array}$ & 2007 & 20 & $\begin{array}{l}\text { Medical ICU patients } \\
\text { with sepsis }\end{array}$ & $\begin{array}{l}1992 \text { ACCP/SCCM [1], } \\
\text { severity graded by } \\
\text { procalcitonin and C- } \\
\text { reactive protein level }\end{array}$ & $\begin{array}{l}\text { Endothelin- } 1 \text { correlates with CRP } \\
\text { and } P C T \text { levels as estimates of level } \\
\text { of sepsis severity ( } P<0.05 \text { for both) }\end{array}$ & $\begin{array}{l}\text { Endothelin-1 correlates with SOFA } \\
\text { score }(p<0.001)\end{array}$ \\
\hline $\begin{array}{l}\text { Weitzberg } \\
\text { et al., [86] }\end{array}$ & 1991 & 16 & $\begin{array}{l}\text { Sepsis (6) and healthy } \\
\text { controls (10) }\end{array}$ & Bone et al., [102] & $\begin{array}{l}\text { Endothelin-1 elevated in sepsis } \\
\text { compared with healthy controls } \\
(11.3 \text { vs. } 2.4 \mathrm{pmol} / \mathrm{l}, P<0.01)\end{array}$ & $\mathrm{n} / \mathrm{a}$ \\
\hline $\begin{array}{l}\text { Furian } \\
\text { et al. [76] }\end{array}$ & 2011 & 45 & $\begin{array}{l}\text { Patients admitted to } \\
\text { ICU with severe sepsis } \\
\text { or septic shock }\end{array}$ & 1992 ACCP/SCCM [1] & & $\begin{array}{l}\text { Endothelin- } 1 \text { levels associated } \\
\text { with left ventricular and right } \\
\text { ventricular function. }(p=0.002)\end{array}$ \\
\hline $\begin{array}{l}\text { Pittet } \\
\text { et al., [87] }\end{array}$ & 1991 & 40 & $\begin{array}{l}\text { Sepsis (14), post- } \\
\text { operative cardiac } \\
\text { surgery (15) and } \\
\text { healthy controls (11) }\end{array}$ & Bone et al., [102] & $\begin{array}{l}\text { Endothelin-1 elevated in septic } \\
\text { patients compared with healthy } \\
\text { controls ( } 19.9 \text { vs } 6.1 \mathrm{pg} / \mathrm{ml}, P< \\
0.0001 \text { ) }\end{array}$ & $\begin{array}{l}\text { Endothelin- } 1 \text { inversely correlated } \\
\text { with cardiac index }(p<0.005) \text {; } \\
\text { correlated with APACHE-II scores } \\
(p<0.01)\end{array}$ \\
\hline
\end{tabular}

ACCP, American College of Chest Physicians; ALI, Acute Lung Injury; APACHE II, Acute Physiology and Chronic Health Evaluation II; ARDS, Acute Respiratory Distress Syndrome; ED, emergency department; MOF, Multiple Organ Failure; SAPS, Simplified Acute Physiology Score; SCCM, Society of Critical Care Medicine; SIRS, Systemic Inflammatory Response Syndrome; SOFA, Sequential Organ Failure Assessment

\section{Soluble VEGF}

Four studies reported a positive association with sepsis, with higher levels in septic patients compared with nonseptic critically ill patients $[77,83,84]$ and healthy controls [82]. In contrast, Van der Heijden et al. did not find a significant difference in soluble VEGF between septic and non-septic ICU patients [45] and Kumpers et al. reported lower serum VEGF levels in patients with sepsis compared to healthy controls [42]. Van der Flier et al. reported significantly elevated VEGF levels in nonsurvivors compared with survivors [83], in contrast to Karlsson et al. who reported significantly lower VEGF levels in non-survivors [82].

\section{Soluble FLT (sFlt)}

Both studies reporting sFLT were prospective studies from the same centre, studying emergency room patients with suspected infections, with non-infected patients serving as controls. There was some overlap between the two studies, with some patients reported in both cohorts. sFLT was shown to be elevated with increasing severity of illness [77], and was also predictive of severe sepsis and mortality, both upon presentation and longitudinally during hospitalization [51].

\section{Endothelin-1}

Two studies reported that endothelin-1 was significantly elevated in patients with sepsis compared with healthy controls [86,87]. An additional two studies reported a correlation with severity of illness as defined by other biomarkers [85] or ACCP/SCCM criteria [81]. There was no documented association between endothelin-1 levels and mortality in the one study that examined this outcome [81].

\section{Mediators of coagulation}

We identified 14 relevant studies studying von Willebrand Factor (vWF) and sepsis (see Table 9-Studies Evaluating von Willebrand Factor). All studies reported assays of either VWF:Ag and/or VWF:RCo activity. Four studies presented data on ADAMTS13 (see Table 10Studies Evaluating ADAMTS13), which reported either ADAMTS13 antigen levels or ADAMTS13 activity.

\section{Von Willebrand factor (vWF)}

\section{Association with sepsis}

Eight studies examined the capability of circulating vWF levels to differentiate patients with sepsis from patients with other illnesses. Two studies found that vWF levels were significantly higher in septic patients compared to patients with systemic inflammation from other causes $[89,90]$, other non-septic critically-ill patients $[45,53,90]$, and healthy controls $[59,89]$. Two studies reported higher levels in patients with sepsis than in patients with SIRS or healthy controls, but the differences did not reach statistical significance [91-93]. In a cohort of patients with ALI/ARDS, Ware et al. reported that vWF was significantly increased in septic patients compared with those without sepsis $(P<0.05)$ [94].

Hovinga et al. in a secondary analysis of a clinical trial, reported that vWF activity was significantly higher in septic patients than in healthy controls, but vWF was 


\begin{tabular}{|c|c|c|c|c|c|c|}
\hline Study & Year & $\mathrm{N}$ & Population & Standard criteria for SIRS/sepsis & Association with sepsis & Other outcomes \\
\hline Claus et al., [89] & 2009 & 63 & $\begin{array}{l}\text { ICU patients with severe sepsis (11), } \\
\text { non-elective cardiac surgery (22), } \\
\text { elective cardiac surgery as ICU } \\
\text { controls (24), and post-exercise as } \\
\text { healthy controls (6) }\end{array}$ & 1992 ACCP/SCCM [1] & $\begin{array}{l}\text { WWF:Ag higher in patients with } \\
\text { sepsis and post non-elective cardiac } \\
\text { surgery than ICU controls }(P<0.05)\end{array}$ & $\begin{array}{l}\text { WWF:Ag shows tendency to discriminate } \\
\text { survivors from nonsurivors }\end{array}$ \\
\hline $\begin{array}{l}\text { Bockmeyer et al., } \\
{[90]}\end{array}$ & 2008 & 57 & $\begin{array}{l}\text { ICU patients with sepsis (11), non- } \\
\text { elective cardiac surgery (22), and } \\
\text { elective cardiac surgery as ICU } \\
\text { controls (24) }\end{array}$ & Not specified & $\begin{array}{l}\text { WWF:Ag higher in sepsis and in non- } \\
\text { elective cardiac surgery than ICU } \\
\text { controls (both } P<0.001 \text { ) }\end{array}$ & $\begin{array}{l}\text { WWF:Ag correlated with mortality }(P< \\
0.05)\end{array}$ \\
\hline $\begin{array}{l}\text { van der Heijden } \\
\text { et al., [45] }\end{array}$ & 2008 & 112 & $\begin{array}{l}\text { Mechanically ventilated patients, } \\
\text { with sepsis (24) and without (88) }\end{array}$ & 1992 ACCP/SCCM [1] & $\begin{array}{l}\text { VWF higher in patients with sepsis } \\
\text { than without sepsis }(P<0.001)\end{array}$ & $\begin{array}{l}\text { WWF correlated with mortality }(P= \\
0.006) \text {; WF higher in those with ALI/ } \\
\text { ARDS than those without }(P<0.001)\end{array}$ \\
\hline $\begin{array}{l}\text { Hovinga et al., } \\
\text { [95] }\end{array}$ & 2007 & 80 & $\begin{array}{l}\text { Medical and surgical ICU patients } \\
\text { with severe sepsis or septic shock } \\
\text { (40), and healthy controls (40) }\end{array}$ & 1992 ACCP/SCCM [1] & $\begin{array}{l}\text { WWF:Ag and WWF:RCO higher in } \\
\text { sepsis than controls }(P<0.001)\end{array}$ & $\begin{array}{l}\text { WWF not correlated with disease severity, } \\
\text { organ dysfunction, or mortality }\end{array}$ \\
\hline Martin et al., [91] & 2007 & 89 & $\begin{array}{l}\text { ICU patients with severe sepsis (30), } \\
\text { sepsis-unrelated organ failure (29), } \\
\text { and healthy controls (30) }\end{array}$ & 1992 ACCP/SCCM [1] & $\begin{array}{l}\text { WWF:Ag tends to differentiate severe } \\
\text { sepsis from sepsis-unrelated organ } \\
\text { failure }(P>0.05)\end{array}$ & WWF:Ag not correlated with mortality \\
\hline $\begin{array}{l}\text { Scherpereel et al., } \\
\text { [53] }\end{array}$ & 2006 & 90 & $\begin{array}{l}\text { ICU patients with sepsis (63), SIRS } \\
\text { (7), and healthy controls (20) }\end{array}$ & 1992 ACCP/SCCM [1] & $\begin{array}{l}\text { WWF higher in sepsis than SIRS }(P< \\
0.02)\end{array}$ & $\begin{array}{l}\text { WF correlated with mortality }(P= \\
\text { 0.039) }\end{array}$ \\
\hline Ware et al., [94] & 2001 & 51 & $\begin{array}{l}\text { ICU patients with ALI, ARDS ( } 45 \% \\
\text { due to sepsis) }\end{array}$ & $\begin{array}{l}\text { Temperature }>38^{\circ} \text { or }<35^{\circ} \mathrm{C} \text {, systolic blood } \\
\text { pressure }<90 \mathrm{mmHg} \text { (or a drop of } 20 \mathrm{~mm} \\
\mathrm{Hg} \text { or more in the systolic blood pressure } \\
\text { from baseline), both present for at least } 2 \mathrm{~h} \text {; } \\
\text { AND a clinically identifiable source of } \\
\text { infection [103] }\end{array}$ & $\begin{array}{l}\text { WWF:Ag higher in patients with } \\
\text { sepsis than those without }(P<0.05)\end{array}$ & $\begin{array}{l}\text { WF correlated with mortality }(P< \\
0.005) \text {; higher in those with longer } \\
\text { duration of ventilation } P<0.005 \text {; not } \\
\text { correlated with illness severity scores } \\
\text { (SAPSII, Lung Injury Score) }\end{array}$ \\
\hline $\begin{array}{l}\text { Garcia-Fernandez } \\
\text { et al., [92] }\end{array}$ & 2000 & 80 & $\begin{array}{l}\text { ICU patients with SIRS and acute } \\
\text { renal failure (40), and healthy } \\
\text { controls (40) }\end{array}$ & 1992 ACCP/SCCM [1] & $\begin{array}{l}\text { WWF higher in SIRS than controls }(P \\
<0.001)\end{array}$ & \\
\hline Bajaj et al., [97] & 1999 & 60 & $\begin{array}{l}\text { Ward and ICU patients with ARDS } \\
\text { (18), at risk of ARDS (15), and } \\
\text { healthy controls (27) }\end{array}$ & Clinical diagnosis of sepsis & $\begin{array}{l}\text { WF does not differentiate patients } \\
\text { with ARDS due to sepsis from other } \\
\text { etiologies }\end{array}$ & $\begin{array}{l}\text { WW higher in ARDS }(P<0.001) \text { and at } \\
\text { risk ARDS }(P<0.01) \text { compared to } \\
\text { controls but did not differ significantly } \\
\text { between these two groups }\end{array}$ \\
\hline Kayal et al., [59] & 1998 & 41 & $\begin{array}{l}\text { ICU patients with severe sepsis or } \\
\text { septic shock ( } 25) \text {, ICU controls (7), } \\
\text { healthy controls (9) }\end{array}$ & 1992 ACCP/SCCM [1] & $\begin{array}{l}\text { WWF:Ag higher in sepsis than } \\
\text { noninfected ICU controls and } \\
\text { healthy controls }(P<0.0001) \text {; higher } \\
\text { in septic shock than those without } \\
\text { septic shock }(P<0.01)\end{array}$ & $\begin{array}{l}\text { WWF:Ag correlated with mortality }(P< \\
0.01) \text {; correlated with SAPS and MOF } \\
\text { score }(r=0.57, P<0.01 \text { for MOF) }\end{array}$ \\
\hline Moss et al., [66] & 1996 & 66 & $\begin{array}{l}\text { ICU patients with sepsis (19), trauma } \\
\text { (36), healthy controls (11) }\end{array}$ & Clinical diagnosis of sepsis & $\begin{array}{l}\text { WWF:Ag higher in septic patients } \\
\text { than trauma patients and controls } \\
\text { (both } P<0.001 \text { ) }\end{array}$ & \\
\hline Moss et al., [98] & 1995 & 96 & $\begin{array}{l}\text { Hospitalized patients at risk of ARDS, } \\
\text { including sepsis (30) }\end{array}$ & Clinical diagnosis of sepsis & & $\begin{array}{l}\text { WF:Ag not predictive of the } \\
\text { development of ARDS }\end{array}$ \\
\hline Lorente et al., [93] & 1993 & 48 & ICU patients with septic shock & 1992 ACCP/SCCM [1] & & WW:Ag not predictive of mortality \\
\hline Rubin et al., [96] & 1990 & 45 & $\begin{array}{l}\text { ICU patients with nonpulmonary } \\
\text { sepsis }\end{array}$ & Clinical diagnosis of sepsis & & $\begin{array}{l}\text { WFF:Ag correlated with mortality }(P< \\
0.005) \text { and ALI }(P<0.01)\end{array}$ \\
\hline
\end{tabular}


Table 10 Studies evaluating ADAMTS13

\begin{tabular}{|c|c|c|c|c|c|c|}
\hline Study & Year & $\mathrm{N}$ & Population & $\begin{array}{l}\text { Standard } \\
\text { criteria for } \\
\text { SIRS/sepsis }\end{array}$ & $\begin{array}{l}\text { Association with } \\
\text { sepsis }\end{array}$ & Other outcomes \\
\hline Claus et al., [89] & 2009 & 63 & $\begin{array}{l}\text { ICU patients with severe sepsis (11), } \\
\text { non-elective cardiac surgery (22), } \\
\text { elective cardiac surgery as ICU } \\
\text { controls (24), and post-exercise as } \\
\text { healthy controls (6) }\end{array}$ & $\begin{array}{l}1992 \text { ACCP/ } \\
\text { SCCM [1] }\end{array}$ & $\begin{array}{l}\text { ADAMTS13 activity } \\
\text { lower in sepsis than } \\
\text { ICU reference group }(P \\
<0.001)\end{array}$ & $\begin{array}{l}\text { ADAMTS13 activity correlated with } \\
\text { mortality }(P<0.05)\end{array}$ \\
\hline $\begin{array}{l}\text { Bockmeyer } \\
\text { et al., [90] }\end{array}$ & 2008 & 57 & $\begin{array}{l}\text { ICU patients with sepsis (11), non- } \\
\text { elective cardiac surgery (22), and } \\
\text { elective cardiac surgery as ICU } \\
\text { controls (24) }\end{array}$ & Not specified & $\begin{array}{l}\text { ADAMTS13 activity } \\
\text { lower in sepsis than } \\
\text { ICU controls } \\
(P<0.01)\end{array}$ & $\begin{array}{l}\text { ADAMTS13 activity correlated with } \\
\text { mortality }(P<0.01)\end{array}$ \\
\hline $\begin{array}{l}\text { Hovinga et al., } \\
\text { [95] }\end{array}$ & 2007 & 80 & $\begin{array}{l}\text { Medical and surgical ICU patients } \\
\text { with severe sepsis or septic shock } \\
(40) \text {, and healthy controls (40) }\end{array}$ & $\begin{array}{l}1992 \text { ACCP/ } \\
\text { SCCM [1] }\end{array}$ & $\begin{array}{l}\text { ADAMTS13 activity } \\
\text { lower in sepsis than } \\
\text { healthy controls }(P< \\
0.001)\end{array}$ & $\begin{array}{l}\text { ADAMTS13 activity not correlated with } \\
\text { disease severity, organ dysfunction, or } \\
\text { mortality }\end{array}$ \\
\hline Martin et al., [91] & 2007 & 89 & $\begin{array}{l}\text { ICU patients with severe sepsis (30), } \\
\text { sepsis-unrelated organ failure (29), } \\
\text { and healthy controls (30) }\end{array}$ & $\begin{array}{l}1992 \text { ACCP/ } \\
\text { SCCM [1] }\end{array}$ & $\begin{array}{l}\text { ADAMTS13 activity } \\
\text { lower in severe sepsis } \\
\text { than sepsis-unrelated } \\
\text { organ failure } \\
(P<0.05) \text { and healthy } \\
\text { controls }(P<0.05)\end{array}$ & $\begin{array}{l}\text { ADAMTS13 activity correlated with } \\
\text { APACHE } I I(r=-0.66, P<0.0001), \\
\text { number of organ failures }(r=-0.66 \text {, } \\
P<0.0001) \text {, and mortality }(P=0.02 \text { by } \\
\text { log rank test) }\end{array}$ \\
\hline
\end{tabular}

ACCP, American College of Chest Physicians; ALI, Acute Lung Injury; APACHE II, Acute Physiology and Chronic Health Evaluation II; ARDS, Acute Respiratory Distress Syndrome; ED, emergency department; MOF, Multiple Organ Failure; SAPS, Simplified Acute Physiology Score; SCCM, Society of Critical Care Medicine; SIRS, Systemic Inflammatory Response Syndrome; SOFA, Sequential Organ Failure Assessment

not correlated with sepsis severity or survival [95]. Two other studies found a significant correlation between VWF and sepsis severity $[59,94]$.

\section{Association with clinical outcome}

Four studies looked at its correlation with ALI/ARDS, with two studies showing its ability to differentiate those with ALI/ARDS from those without $[45,96]$, and two studies showing that it is not predictive of ALI/ARDS $[97,98]$.

Ten of the identified studies presented mortality data, with six studies showing a significant correlation of vWF with mortality $[45,53,59,90,94,96]$, with one study reporting a plasma vWF:Ag of $450 \%$ the upper normal limit predicted death with a sensitivity of $44 \%$ and a specificity of $91 \%$ [94]. Four studies did not find a significant correlation with mortality $[89,91,93,95]$.

\section{ADAMTS13}

Three studies showed that ADAMTS13 is significantly lower in sepsis than other critically ill nonseptic patients [89-91]. One study showed significant correlation with disease severity [91], while a second did not [95]. Three studies showed ADAMTS13 levels correlated with mortality [89-91], although one study did not find a significant correlation [95].

\section{Discussion}

We report a comprehensive and exhaustive systematic review of biomarkers reflecting endothelial activation for the diagnosis, triage and prognostication of sepsis in humans. The reviewed literature demonstrates positive associations between multiple EC-derived molecules and sepsis, supporting the critical role of EC activation in the septic response. Multiple other studies also reported positive associations for mortality and severity of illness, although these results were less consistent than for sepsis per se. Very few studies, however, reported thresholds or receiver operating characteristics that would establish these molecules as clinically-relevant biomarkers in sepsis.

Of the potential biomarkers reviewed, the angiopoeitin$1 / 2$ system may hold the most promise. Multiple studies reported consistent associations between elevations in circulating Ang-2 levels and sepsis in varied samples of critically ill patients. All studies evaluating Ang-2 used standard sepsis definitions, with consistent association between Ang-2 levels and sepsis, as well as relatively consistent associations between Ang-2 and other clinical outcomes. The strength of association is also supported in the identified studies by: (1) a demonstrable doseresponse relationship with higher Ang-2 levels in severe sepsis and organ dysfunction, and increasing with increasing severity of illness, and (2) a temporal progression with Ang-2 levels increasing over time in those patients who developed sepsis and in patients with increasing severity of sepsis as defined by SIRS, sepsis and septic shock. Unfortunately, no studies provided a cut point or threshold that would make Ang-2 clinically useful as a biomarker in the diagnosis or stratification of patients presenting with presumed sepsis.

One general limitation with all of the identified studies is the lack of standardized assays for the studied 
molecules. Very few studies reported threshold values for prognostic analysis or receiver operating characteristics of the potential biomarkers. Furthermore, almost all studies were either single centre or single laboratory, and most assays were non-standardized ELISAs, and thus the absolute values reported in each study may vary according to the type of assay, as well as the type of sample used (for example, plasma vs. serum). These issues led to important limitations in the generalizability and strength of inference that can be drawn from the identified studies. Where possible, we have reported absolute values in the tables to allow readers to appreciate the scope of variation, as well as absolute differences in levels between groups.

There are several limitations to our study. We searched for known endothelial-derived markers by name, and it is possible that other novel markers were missed. We attempted to address this limitation by hand-searching the reference list of identified studies to include all relevant studies of selected endothelialderived markers. Many of the identified publications are single-centre studies or retrospective analyses of previously collected specimens, which limit generalizability to other jurisdictions and populations. As previously mentioned, lack of standardization in the reported assays makes quantitative comparison of a biomarker across studies impossible, and thus we can only report similarities in the direction and relative magnitude of association across studies.

The identified studies were most commonly small prospective or retrospective cohort studies evaluating levels of a potential biomarker in patients with sepsis and a comparative control group. Almost all studies used established consensus criteria for the definition of sepsis to limit misclassification of patients. There was significant heterogeneity in patient populations across studies, however, including patients with presumed sepsis identified in any one of the emergency department, medical ward and medical, surgical and trauma intensive care units. It is conceivable that the receiver operating characteristics of any given biomarker may vary according to the differential inflammatory state, concurrent injuries and pathophysiology of these different patient groups.

If EC-derived biomarkers are to become clinically useful, future work will require standardization of analytical techniques and rigorous evaluation of receiver operating characteristics to define the role and reliability of these molecules. Although some recent studies reported receiver operating characteristics or threshold biomarker levels, the lack of standard assays limits the interpretation and clinical utility of these efforts. Future work must include: (1) the description of the operating characteristics of biomarkers, (2) the use of explicitly defined threshold serum levels, (3) measured with a standardized assay.

It may be impossible to achieve the high degree of sensitivity and specificity required for clinical diagnosis with a single biomarker assay, and a multiplexed combination of markers may be necessary to improve predictive value and clinical utility of biomarkers. Careful selection and combinations of biomarkers with relative specificity to disease states (for example, the observed association between Ang-2 and ARDS/pulmonary leak, or the differential association of sVCAM and sE-Selectin in fungal sepsis) would be one way of improving the clinical utility of these novel molecules. Following identification of useful serum biomarker thresholds with standard assays, we speculate that evaluation of multiplexed biomarker panels may prove useful as a diagnostic strategy.

Given the epidemiologic rise of sepsis in both the developed [99] and developing world [100], novel diagnostics and therapeutics for sepsis are urgently needed, and endothelial-derived biomarkers will likely play a crucial role.

\section{Conclusions}

We report a systematic review of the published literature and findings that multiple molecules reflecting endothelial activation are correlated with the presence of sepsis in humans. We also found variable degrees of correlation between biomarkers and other clinical outcomes. The clinical utility or application of these molecules as biomarkers in sepsis, however, is limited by a lack of standardization in analytical assays, a lack of data regarding receiver operating characteristics and, in the few cases where thresholds have been reported, a lack of validation in representative patient populations.

\section{Key messages}

- Multiple molecules reflecting endothelial activation are correlated with the presence of sepsis in humans and other clinically important outcomes.

- The clinical utility or application of these molecules as biomarkers in sepsis; however, is limited by a lack of standardization in analytical assays, a lack of data regarding receiver operating characteristics and a lack of validation.

- The consistent association with sepsis, demonstrable dose-response relationship, and temporal progression in patients who develop sepsis make Angiopoietin-2 an attractive potential biomarker in sepsis.

- Future research should focus on standardization of assays and identification of cut points or thresholds that make biomarkers clinically useful in the 
diagnosis or stratification of patients presenting with presumed sepsis.

- Evaluation of multiplexed panels with biomarkers of differential response characteristics may prove useful as a diagnostic strategy.

\section{Additional material}

\section{Additional file 1: Search Strategy.}

\section{Abbreviations}

ACCP: American College of Chest Physicians; ADAMTS13: a disintegrin and metalloproteinase with a thrombospondin type 1 motif, Member 13; ALI: Acute Lung Injury; Ang 1/2: Angiopoeitin 1/2; APACHE II: Acute Physiology and Chronic Health Evaluation II; ARDS: Acute Respiratory Distress Syndrome; EC: endothelial cell; ED: emergency department; ICU: intensive care unit; MOF: Multiple Organ Failure; SAPS: Simplified Acute Physiology Score; SCCM: Society of Critical Care Medicine; s-Flt: soluble Flt (soluble Vascular Endothelial Growth Factor receptor); sICAM-1: Intercellular Adhesion Molecule-1; SIRS: Systemic Inflammatory Response Syndrome; SOFA: Sequential Organ Failure Assessment; sVCAM-1: Vascular Cell Adhesion molecule-1; VEGF: Vascular Endothelial Growth Factor; vWF: von Willebrand Factor; vWFA: von Willebrand Factor antigen; VWFRCo: von Willebrand Factor ristocetin cofactor.

\section{Acknowledgements}

WCL is the recipient of a Canada Research Chair (Infectious Diseases and Inflammation) from the Canadian Institutes of Health Research (CIHR).

\section{Author details}

${ }^{1}$ Division of Hematology, University of British Columbia, Vancouver General Hospital, 855 12th Ave W, Vancouver, BC V5Z 1M9, Canada. ²Divisions of Pediatric Infectious Disease and Critical Care, University of Toronto, Hospital for Sick Children, 555 University Avenue, Toronto, ON M5G 1X8, Canada. ${ }^{3}$ McLaughlin-Rotman Centre for Global Health, University Health Network, 101 College Street, Suite 406 Toronto, ON M5G 1L7, Canada. ${ }^{4}$ Department of Medicine, University of Toronto, 1 King's College Circle Medical Sciences Building-Room 2109, Toronto, ON M5S 1A8, Canada. Interdepartmental Division of Critical Care Medicine, University of Toronto, Queen Street Wing, Room 4-042, 30 Bond Street, Toronto, ON M5B 1W8, Canada.

\section{Authors' contributions}

KX conceived of the study, participated in study design, participated in literature review and data extraction, and drafted the initial manuscript. WCL conceived of the study, participated in study design and provided critical revisions to the manuscript for intellectual content. JMS participated in study design, participated in literature review and data extraction, drafted the initial manuscript and provided critical revisions to the manuscript for intellectual content. SM participated in the literature review and data extraction, and drafted the initial manuscript. All authors participated in data synthesis and interpretation of results. All authors read and approved the final manuscript.

\section{Competing interests}

The authors declare they have no competing interests.

Received: 14 October 2011 Revised: 29 November 2011 Accepted: 16 January 2012 Published: 16 January 2012

\section{References}

1. Bone RC, Balk RA, Cerra FB, Dellinger RP, Fein AM, Knaus WA, Schein RM, Sibbald WJ: Definitions for sepsis and organ failure and guidelines for the use of innovative therapies in sepsis. The ACCP/SCCM Consensus Conference Committee. American College of Chest Physicians/Society of Critical Care Medicine. Chest 1992, 101:1644-1655.
2. Levy MM, Fink MP, Marshall JC, Abraham E, Angus D, Cook D, Cohen J, Opal SM, Vincent JL, Ramsay G: 2001 SCCM/ESICM/ACCP/ATS/SIS International Sepsis Definitions Conference. Crit Care Med 2003, 31:1250-1256.

3. Angus DC, Linde-Zwirble WT, Lidicker J, Clermont G, Carcillo J, Pinsky MR: Epidemiology of severe sepsis in the United States: analysis of incidence, outcome, and associated costs of care. Crit Care Med 2001, 29:1303-1310.

4. Biomarkers and surrogate endpoints: preferred definitions and conceptual framework. Clin Pharmacol Ther 2001, 69:89-95.

5. Pierrakos C, Vincent JL: Sepsis biomarkers: a review. Crit Care 2010, 14:R15.

6. Hotchkiss RS, Karl IE: Endothelial cell apoptosis in sepsis: a case of habeas corpus? Crit Care Med 2004, 32:901-902.

7. Hotchkiss RS, Tinsley KW, Swanson PE, Karl IE: Endothelial cell apoptosis in sepsis. Crit Care Med 2002, 30:5225-228.

8. Hemmer CJ, Vogt A, Unverricht M, Krause R, Lademann M, Reisinger EC: Malaria and bacterial sepsis: similar mechanisms of endothelial apoptosis and its prevention in vitro. Crit Care Med 2008, 36:2562-2568.

9. Hack CE, Zeerleder S: The endothelium in sepsis: source of and a target for inflammation. Crit Care Med 2001, 29:521-27.

10. Matsuda N, Teramae H, Yamamoto S, Takano K, Takano Y, Hattori Y: Increased death receptor pathway of apoptotic signaling in septic mouse aorta: effect of systemic delivery of FADD siRNA. Am J Physiol Heart Circ Physiol 2010, 298:H92-101.

11. Reinhart K, Bayer O, Brunkhorst F, Meisner M: Markers of endothelial damage in organ dysfunction and sepsis. Crit Care Med 2002, 30:S302-312.

12. Schouten M, Wiersinga WJ, Levi M, van der Poll T: Inflammation, endothelium, and coagulation in sepsis. J Leukoc Biol 2008, 83:536-545.

13. Aird WC: The role of the endothelium in severe sepsis and multiple organ dysfunction syndrome. Blood 2003, 101:3765-3777.

14. Vallet B: Bench-to-bedside review: endothelial cell dysfunction in severe sepsis: a role in organ dysfunction? Crit Care 2003, 7:130-138.

15. Guyatt GH, Oxman AD, Vist GE, Kunz R, Falck-Ytter Y, Alonso-Coello P, Schünemann HJ: GRADE: an emerging consensus on rating quality of evidence and strength of recommendations. BMJ 2008, 336:924-926.

16. Trzeciak S, Jones AE, Shapiro NI, Pusateri AE, Arnold RC, Rizzuto M, Arora T, Parrillo JE, Dellinger RP, Emergency Medicine Shock Research Network (EMShockNet) investigators: A prospective multicenter cohort study of the association between global tissue hypoxia and coagulation abnormalities during early sepsis resuscitation. Crit Care Med 2010, 38:1092-1100.

17. Ganter MT, Cohen MJ, Brohi K, Chesebro BB, Staudenmayer KL, Rahn P, Christiaans SC, Bir ND, Pittet JF: Angiopoietin-2, marker and mediator of endothelial activation with prognostic significance early after trauma? Ann Surg 2008, 247:320-326.

18. Cepkova M, Brady S, Sapru A, Matthay MA, Church G: Biological markers of lung injury before and after the institution of positive pressure ventilation in patients with acute lung injury. Critical Care 2006, 10:R126.

19. Yano K, Liaw PC, Mullington JM, Shih SC, Okada H, Bodyak N, Kang PM, Toltl L, Belikoff B, Buras J, Simms BT, Mizgerd JP, Carmeliet P, Karumanchi SA, Aird WC: Vascular endothelial growth factor is an important determinant of sepsis morbidity and mortality. J Exp Med 2006, 203:1447-1458.

20. Megarbane B, Marchal P, Marfaing-Koka A, Belliard O, Jacobs F, Chary I, Brivet FG: Increased diffusion of soluble adhesion molecules in meningitis, severe sepsis and systemic inflammatory response without neurological infection is associated with intrathecal shedding in cases of meningitis. Intensive Care Med 2004, 30:867-874

21. Fujimi S, Ogura H, Tanaka H, Koh T, Hosotsubo H, Nakamori $Y$, Kuwagata Y, Shimazu T, Sugimoto H: Activated polymorphonuclear leukocytes enhance production of leukocyte microparticles with increased adhesion molecules in patients with sepsis. J Trauma 2002, 52:443-448.

22. Poeze M, Ramsay G, Buurman WA, Greve JW, Dentener M, Takala J: Increased hepatosplanchnic inflammation precedes the development of organ dysfunction after elective high-risk surgery. Shock 2002, 17:451-458.

23. Bechard D, Meignin V, Scherpereel A, Oudin S, Kervoaze G, Bertheau P, Janin A, Tonnel A, Lassalle P: Characterization of the secreted form of endothelial-cell-specific molecule 1 by specific monoclonal antibodies. J Vasc Res 2000, 37:417-425. 
24. Giannoudis PV, Smith RM, Banks RE, Windsor AC, Dickson RA, Guillou PJ: Stimulation of inflammatory markers after blunt trauma. Br J Surg 1998, 85:986-990.

25. McGill SN, Ahmed NA, Christou NV: Increased plasma von Willebrand factor in the systemic inflammatory response syndrome is derived from generalized endothelial cell activation. Crit Care Med 1998, 26:296-300.

26. Kneidinger R, Bahrami S, Redl H, Schlag G, Robinson M, Weichselbraun I, Cremer J: Evaluation of a soluble E-selectin enzyme-linked immunosorbent assay under posttraumatic conditions. J Lab Clin Med 1996, 128:520-523

27. Hesselvik JF, Blomback M, Brodin B, Maller R: Coagulation, fibrinolysis, and kallikrein systems in sepsis: relation to outcome. Crit Care Med 1989, 17:724-733.

28. van der Heijden M, van Nieuw Amerongen GP, van Hinsbergh WW, Groeneveld AB: The interaction of soluble Tie2 with angiopoietins and pulmonary vascular permeability in septic and nonseptic critically ill patients. Shock 2010, 33:263-268.

29. Kumpers P, Hafer C, David S, Hecker H, Lukasz A, Fliser D, Haller H, Kielstein JT, Faulhaber-Walter R: Angiopoietin-2 in patients requiring renal replacement therapy in the ICU: relation to acute kidney injury, multiple organ dysfunction syndrome and outcome. Intensive Care Med 2010, 36:462-470.

30. Gando S, Kameue T, Matsuda N, Hayakawa M, Hoshino H, Kato H: Serial changes in neutrophil-endothelial activation markers during the course of sepsis associated with disseminated intravascular coagulation. Thromb Res 2005, 116:91-100

31. von Heymann C, Langenkamp J, Dubisz N, von Dossow V, Schaffartzik W, Kern H, Kox WJ, Spies C: Posttraumatic immune modulation in chronic alcoholics is associated with multiple organ dysfunction syndrome. $J$ Trauma 2002, 52:95-103.

32. Grad S, Ertel W, Keel M, Infanger M, Vonderschmitt DJ, Maly FE: Strongly enhanced serum levels of vascular endothelial growth factor (VEGF) after polytrauma and burn. Clin Chem Lab Med 1998, 36:379-383.

33. Rivers EP, Kruse JA, Jacobsen G, Shah K, Loomba M, Otero R, Childs EW: The influence of early hemodynamic optimization on biomarker patterns of severe sepsis and septic shock. Crit Care Med 2007, 35:2016-2024.

34. Fang $X L$, Fang $Q$, Cai GL, Yan J: [Effect of fluid resuscitation on adhesion molecule and hemodynamics in patients with severe sepsis]. Zhongguo Wei Zhong Bing Ji Jiu Yi Xue 2006, 18:539-541.

35. Boldt J, Papsdorf M, Piper SN, Rothe A, Hempelmann G: Continuous heparinization and circulating adhesion molecules in the critically ill. Shock 1999, 11:13-18

36. Kuang $X, M a K$, Duan $T$ : [The significance of postburn changes in plasma levels of ICAM-1, IL-10 and TNFalpha during early postburn stage in burn patients]. Zhonghua Shao Shang Za Zhi 2002, 18:302-304.

37. Li PJ, Yang XH, Zhang LP, Cao W, Qin J, Yao W: [Clinical significance of soluble selectins and matrix metalloproteinases- 9 in patients after successful cardiopulmonary resuscitation]. Zhongguo Wei Zhong Bing Ji Jiu Yi Xue 2004, 16:137-141.

38. Orfanos SE, Kotanidou A, Glynos C, Athanasiou C, Tsigkos S, Dimopoulou I, Sotiropoulou C, Zakynthinos S, Armaganidis A, Papapetropoulos A, Roussos C: Angiopoietin-2 is increased in severe sepsis: correlation with inflammatory mediators. Crit Care Med 2007, 35:199-206.

39. Siner JM, Bhandari $V$, Engle KM, Elias JA, Siegel MD: Elevated serum angiopoietin 2 levels are associated with increased mortality in sepsis. Shock 2009, 31:348-353.

40. Giamarellos-Bourboulis EJ, Kanellakopoulou K, Pelekanou A, Tsaganos T, Kotzampassi K: Kinetics of angiopoietin-2 in serum of multi-trauma patients: correlation with patient severity. Cytokine 2008, 44:310-313.

41. Kranidioti H, Orfanos SE, Vaki I, Kotanidou A, Raftogiannis M, Dimopoulou I, Kotsaki A, Savva A, Papapetropoulos A, Armaganidis A, GiamarellosBourboulis EJ: Angiopoietin-2 is increased in septic shock: evidence for the existence of a circulating factor stimulating its release from human monocytes. Immunol Lett 2009, 125:65-71.

42. Kumpers P, Lukasz A, David S, Horn R, Hafer C, Faulhaber-Walter R, Fliser D, Haller $\mathrm{H}$, Kielstein JT: Excess circulating angiopoietin-2 is a strong predictor of mortality in critically ill medical patients. Crit Care 2008, 12: R147.

43. Parikh SM, Mammoto T, Schultz A, Yuan HT, Christiani D, Karumanchi SA, Sukhatme VP: Excess circulating angiopoietin-2 may contribute to pulmonary vascular leak in sepsis in humans. PLoS Med 2006, 3:e46.
44. Davis JS, Yeo TW, Piera KA, Woodberry T, Celermajer DS, Stephens DP, Anstey NM: Angiopoietin-2 is increased in sepsis and inversely associated with nitric oxide-dependent microvascular reactivity. Crit Care 2010, 14:R89.

45. van der Heijden $M$, van Nieuw Amerongen GP, Koolwijk $P$, van Hinsbergh W, Groeneveld AB: Angiopoietin-2, permeability oedema, occurrence and severity of ALI/ARDS in septic and non-septic critically ill patients. Thorax 2008, 63:903-909.

46. Knaus WA, Draper EA, Wagner DP, Zimmerman JE: APACHE II: a severity of disease classification system. Crit Care Med 1985, 13:818-829.

47. Vincent JL, Moreno R, Takala J, Willatts S, De Mendonca A, Bruining H, Reinhart CK, Suter PM, Thijs LG: The SOFA (Sepsis-related Organ Failure Assessment) score to describe organ dysfunction/failure. On behalf of the Working Group on Sepsis-Related Problems of the European Society of Intensive Care Medicine. Intensive Care Med 1996, 22:707-710.

48. Ricciuto DR, dos Santos CC, Hawkes M, Toltl LJ, Conroy AL, Rajwans N, Lafferty El, Cook DJ, Fox-Robichaud A, Kahnamoui K, Kain KC, Liaw PC, Liles WC: Angiopoietin-1 and angiopoietin-2 as clinically informative prognostic biomarkers of morbidity and mortality in severe sepsis. Crit Care Med 2011, 39:702-710

49. Ebihara I, Hirayama K, Nagai M, Kakita T, Sakai K, Tajima R, Sato C, Kurosawa H, Togashi A, Okada A, Usui J, Yamagata K, Kobayashi M: Angiopoietin balance in septic shock patients with acute lung injury: effect of direct hemoperfusion with polymyxin B-immobilized fiber. Ther Apher Dial 2011, 15:349-354.

50. Page AV, Kotb M, McGeer A, Low DE, Kain KC, Liles WC: Systemic dysregulation of angiopoietin-1/2 in streptococcal toxic shock syndrome. Clin Infect Dis 2011, 52:e157-161.

51. Shapiro N, Schuetz P, Yano K, Sorasaki M, Parikh SM, Jones AE, Trzeciak S, Ngo L, Aird WC: The association of endothelial cell signaling, severity of illness, and organ dysfunction in sepsis. Crit Care 2010, 14:R182.

52. Schuetz $P$, Jones $A E$, Aird WC, Shapiro NI: Endothelial cell activation in emergency department patients with sepsis-related and non-sepsisrelated hypotension. Shock 2011, 36:104-108.

53. Scherpereel A, Depontieu F, Grigoriu B, Cavestri B, Tsicopoulos A, Gentina T, Jourdain M, Pugin J, Tonnel AB, Lassalle P: Endocan, a new endothelial marker in human sepsis. Crit Care Med 2006, 34:532-537.

54. Stief TW, ljagha O, Weiste B, Herzum I, Renz H, Max M: Analysis of hemostasis alterations in sepsis. Blood Coagul Fibrinolysis 2007, 18:179-186.

55. Hofer S, Brenner T, Bopp C, Steppan J, Lichtenstern C, Weitz J, Bruckner T, Martin E, Hoffmann U, Weigand MA: Cell death serum biomarkers are early predictors for survival in severe septic patients with hepatic dysfunction. Crit Care 2009, 13:R93.

56. Kinoshita $M$, Ono S, Mochizuki H: Neutrophil-related inflammatory mediators in septic acute respiratory distress syndrome. J Intensive Care Med 2002, 17:308-316.

57. Paterson RL, Galley HF, Dhillon JK, Webster NR: Increased nuclear factor kappa B activation in critically ill patients who die. Crit Care Med 2000 28:1047-1051.

58. Weigand MA, Schmidt H, Pourmahmoud M, Zhao Q, Martin E, Bardenheuer HJ: Circulating intercellular adhesion molecule-1 as an early predictor of hepatic failure in patients with septic shock. Crit Care Med 1999, 27:2656-2661.

59. Kayal S, Jais JP, Aguini N, Chaudiere J, Labrousse J: Elevated circulating Eselectin, intercellular adhesion molecule 1, and von Willebrand factor in patients with severe infection. Am J Respir Crit Care Med 1998, 157:776-784

60. Boldt J, Muller M, Heesen M, Papsdorf M, Hempelmann G: Does age influence circulating adhesion molecules in the critically ill? Crit Care Med 1997, 25:95-100

61. Egerer K, Rohr U, Krausch D, Kox W: The circulating adhesion molecules sICAM-1 and sE-selection in patients with sepsis. Anaesthesist 1997. 46:592-598.

62. Takakuwa T, Endo S, Inada K, Kasai T, Yamada Y, Ogawa M: Assessment of inflammatory cytokines, nitrate/nitrite, type II phospholipase $\mathrm{A} 2$, and soluble adhesion molecules in systemic inflammatory response syndrome. Res Commun Mol Pathol Pharmacol 1997, 98:43-52.

63. Boldt J, Muller M, Kuhn D, Linke LC, Hempelmann G: Circulating adhesion molecules in the critically ill: a comparison between trauma and sepsis patients. Intensive Care Med 1996, 22:122-128. 
64. Endo S, Inada K, Kasai T, Takakuwa T, Yamada Y, Koike S, Wakabayashi G, Niimi M, Taniguchi S, Yoshida M: Levels of soluble adhesion molecules and cytokines in patients with septic multiple organ failure. J Inflamm 1995, 46:212-219.

65. Cowley HC, Heney D, Gearing AJ, Hemingway I, Webster NR: Increased circulating adhesion molecule concentrations in patients with the systemic inflammatory response syndrome: a prospective cohort study. Crit Care Med 1994, 22:651-657.

66. Moss M, Gillespie MK, Ackerson L, Moore FA, Moore EE, Parsons PE: Endothelial cell activity varies in patients at risk for the adult respiratory distress syndrome. Crit Care Med 1996, 24:1782-1786.

67. Nakae H, Endo S, Inada K, Takakuwa T, Kasai T: Changes in adhesion molecule levels in sepsis. Res Commun Mol Pathol Pharmacol 1996, 91:329-338.

68. Sessler CN, Windsor AC, Schwartz M, Watson L, Fisher BJ, Sugerman HJ, Fowler AA: Circulating ICAM-1 is increased in septic shock. Am J Respir Crit Care Med 1995, 151:1420-1427.

69. Presterl E, Lassnigg A, Mueller-Uri P, El-Menyawi I, Graninger W: Cytokines in sepsis due to Candida albicans and in bacterial sepsis. Eur Cytokine Netw 1999, 10:423-430

70. Hynninen M, Valtonen M, Markkanen H, Vaara M, Kuusela P, Jousela I, Piilonen A, Takkunen O: Interleukin 1 receptor antagonist and E-selectin concentrations: a comparison in patients with severe acute pancreatitis and severe sepsis. J Crit Care 1999, 14:63-68.

71. Takala A, Jousela I, Jansson SE, Olkkola KT, Takkunen O, Orpana A, Karonen SL, Repo H: Markers of systemic inflammation predicting organ failure in community-acquired septic shock. Clin Sci 1999, 97:529-538.

72. Osmanovic N, Romijn FPHTM, Joop K, Sturk A, Nieuwland R: Soluble selectins in sepsis: Microparticle-associated, but only to a minor degree. Thromb Haemost 2000, 84:731-732.

73. Froon AH, Bonten MJ, Gaillard CA, Greve JW, Dentener MA, de Leeuw PW, Drent M, Stobberingh EE, Buurman WA: Prediction of clinical severity and outcome of ventilator-associated pneumonia. Comparison of simplified acute physiology score with systemic inflammatory mediators. Am J Resp Crit Care Med 1998, 158:1026-1031.

74. Geppert A, Zorn G, Karth GD, Haumer M, Gwechenberger M, KollerStrametz J, Heinz G, Huber K, Siostrzonek P: Soluble selectins and the systemic inflammatory response syndrome after successful cardiopulmonary resuscitation. Crit Care Med 2000, 28:2360-2365.

75. Simons RK, Hoyt DB, Winchell RJ, Rose RM, Holbrook T: Elevated selectin levels after severe trauma: a marker for sepsis and organ failure and a potential target for immunomodulatory therapy. J Trauma 1996, 41:653-662.

76. Furian T, Aguiar C, Prado K, Ribeiro RV, Becker L, Martinelli N, Clausell N, Rohde LE, Biolo A: Ventricular dysfunction and dilation in severe sepsis and septic shock: Relation to endothelial function and mortality. J Crit Care 2011.

77. Shapiro NI, Yano K, Okada H, Fischer C, Howell M, Spokes KC, Ngo L, Angus DC, Aird WC: A prospective, observational study of soluble FLT-1 and vascular endothelial growth factor in sepsis. Shock 2008, 29:452-457.

78. Knapp S, Thalhammer F, Locker GJ, Laczika K, Hollenstein U, Frass M, Winkler S, Stoiser B, Wilfing A, Burgmann $\mathrm{H}$ : Prognostic value of MIP-1 alpha, TGF-beta 2, sELAM-1, and SVCAM-1 in patients with gram-positive sepsis. Clin Immunol Immunopathol 1998, 87:139-144.

79. Cummings CJ, Sessler CN, Beall LD, Fisher BJ, Best AM, Fowler AA: Soluble Eselectin levels in sepsis and critical illness. Correlation with infection and hemodynamic dysfunction. Am J Resp Crit Care Med 1997, 156:431-437.

80. Newman W, Beall LD, Carson CW, Hunder GG, Graben N, Randhawa ZI, Gopal TV, Wiener-Kronish J, Matthay MA: Soluble E-selectin is found in supernatants of activated endothelial cells and is elevated in the serum of patients with septic shock. J Immunol 1993, 150:644-654.

81. Schuetz P, Christ-Crain M, Morgenthaler NG, Struck J, Bergmann A, Muller B: Circulating precursor levels of endothelin-1 and adrenomedullin, two endothelium-derived, counteracting substances, in sepsis. Endothelium 2007, 14:345-351.

82. Karlsson S, Pettila V, Tenhunen J, Lund V, Hovilehto S, Ruokonen E, Finnsepsis Study G: Vascular endothelial growth factor in severe sepsis and septic shock. Anesth Analg 2008, 106:1820-1826.

83. van der Flier M, van Leeuwen HJ, van Kessel KP, Kimpen JL, Hoepelman Al, Geelen SP: Plasma vascular endothelial growth factor in severe sepsis. Shock 2005, 23:35-38.

84. Rafat N, Hanusch C, Brinkkoetter PT, Schulte J, Brade J, Zijlstra JG, van der Woude FJ, van Ackern K, Yard BA, Beck GC: Increased circulating endothelial progenitor cells in septic patients: correlation with survival. Crit Care Med 2007, 35:1677-1684.
85. Piechota M, Banach M, Irzmanski R, Barylski M, Piechota-Urbanska M, Kowalski J, Pawlicki L: Plasma endothelin-1 levels in septic patients. J Intensive Care Med 2007, 22:232-239.

86. Weitzberg E, Lundberg JM, Rudehill A: Elevated plasma levels of endothelin in patients with sepsis syndrome. Circ Shock 1991, 33:222-227.

87. Pittet JF, Morel DR, Hemsen A, Gunning K, Lacroix JS, Suter PM, Lundberg JM: Elevated plasma endothelin-1 concentrations are associated with the severity of illness in patients with sepsis. Ann Surg 1991, 213:261-264

88. Yang K-Y, Liu K-T, Chen Y-C, Chen C-S, Lee Y-C, Perng R-P, Feng J-Y: Plasma soluble vascular endothelial growth factor receptor-1 levels predict outcomes of pneumonia-related septic shock patients: a prospective observational study. Critical Care 2011, 15:R11

89. Claus RA, Bockmeyer CL, Budde U, Kentouche K, Sossdorf M, Hilberg T, Schneppenheim R, Reinhart K, Bauer M, Brunkhorst FM, Losche W: Variations in the ratio between von Willebrand factor and its cleaving protease during systemic inflammation and association with severity and prognosis of organ failure. Thromb Haemost 2009, 101:239-247.

90. Bockmeyer CL, Claus RA, Budde U, Kentouche K, Schneppenheim R, Losche W, Reinhart K, Brunkhorst FM: Inflammation-associated ADAMTS13 deficiency promotes formation of ultra-large von Willebrand factor. Haematologica 2008, 93:137-140.

91. Martin K, Borgel D, Lerolle N, Feys HB, Trinquart L, Vanhoorelbeke K, Deckmyn H, Legendre P, Diehl JL, Baruch D: Decreased ADAMTS-13 (A disintegrin-like and metalloprotease with thrombospondin type 1 repeats) is associated with a poor prognosis in sepsis-induced organ failure. Crit Care Med 2007, 35:2375-2382.

92. Garcia-Fernandez N, Montes R, Purroy A, Rocha E: Hemostatic disturbances in patients with systemic inflammatory response syndrome (SIRS) and associated acute renal failure (ARF). Thromb Res 2000, 100:19-25.

93. Lorente JA, Garcia-Frade LJ, Landin L, de Pablo R, Torrado C, Renes E, Garcia-Avello A: Time course of hemostatic abnormalities in sepsis and its relation to outcome. Chest 1993, 103:1536-1542.

94. Ware LB, Conner ER, Matthay MA: von Willebrand factor antigen is an independent marker of poor outcome in patients with early acute lung injury. Crit Care Med 2001, 29:2325-2331.

95. Hovinga JAK, Zeerleder S, Kessler P, Romani de Wit T, van Mourik JA, Hack CE, ten Cate H, Reitsma PH, Wuillemin WA, Lammle B: ADAMTS-13, von Willebrand factor and related parameters in severe sepsis and septic shock. J Thromb Haemost 2007, 5:2284-2290.

96. Rubin DB, Wiener-Kronish JP, Murray JF, Green DR, Turner J, Luce JM, Montgomery AB, Marks JD, Matthay MA: Elevated von Willebrand factor antigen is an early plasma predictor of acute lung injury in nonpulmonary sepsis syndrome. J Clin Invest 1990, 86:474-480.

97. Bajaj MS, Tricomi SM: Plasma levels of the three endothelial-specific proteins von Willebrand factor, tissue factor pathway inhibitor, and thrombomodulin do not predict the development of acute respiratory distress syndrome. Intensive Care Med 1999, 25:1259-1266.

98. Moss M, Ackerson L, Gillespie MK, Moore FA, Moore EE, Parsons PE: von Willebrand factor antigen levels are not predictive for the adult respiratory distress syndrome. Am J Respir Crit Care Med 1995, 151:15-20.

99. Martin GS, Mannino DM, Eaton S, Moss M: The epidemiology of sepsis in the United States from 1979 through 2000. N Engl J Med 2003, 348:1546-1554

100. Sankar J, Lodha R, Kabra SK: Management of septic shock: where do we stand? Indian J Pediatr 2008, 75:1167-1169.

101. Yang KY, Liu KT, Chen YC, Chen CS, Lee YC, Perng RP, Feng JY: Plasma soluble vascular endothelial growth factor receptor-1 levels predict outcomes of pneumonia-related septic shock patients: a prospective observational study. Crit Care 2011, 15:R11.

102. Bone RC, Fisher CJ Jr, Clemmer TP, Slotman GJ, Metz CA, Balk RA: Sepsis syndrome: a valid clinical entity. Methylprednisolone Severe Sepsis Study Group. Crit Care Med 1989, 17:389-393.

103. Doyle RL, Szaflarski N, Modin GW, Wiener-Kronish JP, Matthay MA: Identification of patients with acute lung injury. Predictors of mortality. Am J Respir Crit Care Med 1995, 152:1818-1824.

doi:10.1186/cc11145

Cite this article as: Xing et al: Clinical utility of biomarkers of endothelial activation in sepsis-a systematic review. Critical Care 2012 16: R7. 